\title{
FRAUD, DISPUTE, AND THE CONSUMER: RESPONDING TO CONSUMER COMPLAINTS*
}

\author{
ERIC H. STEele†
}

\section{INTRODUCTION}

Consumer grievances are characterized alternatively as the result of fraudulent and deceptive business practices and as breaches of contract and misunderstandings. The moral images of the parties and the nature of the problem are quite different in these separate ways of defining the situation, and different responses result. If the primary problem is perceived to be the existence of sly and predatory businessmen scheming to defraud and deceive innocent and unwary consumers, then a law enforcement response is appropriate. This perception of the situation sees deviant outsiders ${ }^{1}$ (the predatory businessmen) and victims (the consumers). What is called for is the authoritative pronouncement and enforcement of rules outlawing such deviant conduct.

The definition of the problem as deviant business conduct leads to the now common declaration that fraudulent and deceptive practices in consumer transactions are illegal. ${ }^{2}$ Jurisdictions vary as to exact proscriptions, legal sanctions, and mechanisms of enforcement. ${ }^{3}$ All such legislative proscriptions share

* This research is the product of a study sponsored by the American Bar Foundation. A special acknowledgment is due to Felice J. Levine, Research Social Scientist, American Bar Foundation, for her helpful advice and support in the early phases of this study. I am also indebted to those who commented generously and helpfully on the manuscript of this article, among whom are Jan Brakel, James Jacobs, Spencer Kimball, Dorothy Maddi, Raymond Nimmer, H. Laurence Ross, Hans Zeisel, and Franklin Zimring. The cooperation and helpfulness of Howard R. Kaufman, Assistant Attorney General of Illinois and Chief of the Consumer Fraud and Protection Division, are gratefully acknowledged. The views expressed herein are those of the author and not the Consumer Fraud and Protection Division or the American Bar Foundation.

$\dagger$ Research Attorney, American Bar Foundation. A.B. 1963, Yale University; J.D. 1967, Harvard University. Member, Illinois Bar.

${ }^{1} \mathrm{Cf}$. H. Becker, Outsiders (1963).

2 See National Association of Atrorneys General, Committee on the Office of Attorney General, Report on the Office of Attorney General 395-421 (Feb. 1971) [hereinafter cited as NAAG REPORT].

${ }^{3}$ See, e.g., National Institute for Consumer Justice, Consumer Protection in the States and Local Communities (Staff Study V, 1972). 
a criminal or quasi-criminal definition of the task as one of prosecuting, punishing, deterring, and preventing intentional, deviant, and normatively unacceptable conduct. ${ }^{4}$ I shall call this the law enforcement stance. It is act-oriented. It focuses on the normative status and the practices of the business involved, setting as its task the prevention of future improper practices.

While fraudulent and deceptive practices may be ethically and legally clear-cut in theory, they are often extremely difficult to distinguish in practice from other sorts of business conduct. The facts are hard to ascertain, to interpret, and to prove. Legally, fraud includes the element of intent. Where there is no intent to defraud there may be a dispute, and perhaps a breach of contract, but not fraud. Where, for example, a consumer buys a secondhand automobile that does not work properly and the seller refuses to repair it without charge, the distinctions among fraud, breach of warranty, and hard luck hinge on the terms of the contract and the elusive intent of the seller. Another basic fact is that many disputes may appear in isolation to be misunderstandings or breaches of contract, but come into focus as fraudulent when they are seen as parts of a pattern of similar conduct. The classic fraudulent scheme known as "bait and switch" is a good illustration. A store advertises a vacuum cleaner for sale at "the amazing low price" of $\$ 39.99$. When I go to buy the machine I am greeted by a helpful, friendly salesman who shows me the $\$ 39.99$ vacuum cleaner, explains its deficiencies to me, and then aggressively urges that the $\$ 79.99$ deluxe home-cleaning model is a far superior machine and a much better deal. Viewing his argument in isolation, I might conclude that the salesman is right. He may be helping me. If, however, I discover that three salesmen in the store make this approach routinely, and that the store has in stock fifty of the $\$ 79.99$ cleaners and only three of the $\$ 39.99$ machines, I may see the matter much differently. What was an ambiguous, isolated case takes its place as part of a pattern of business practice and leads to a very different interpretation of each case that makes up the pattern. ${ }^{5}$

In concrete cases, the line between fraudulent and acceptable business practices is so unclear that there is a general re-

${ }^{4}$ I will not deal with the difficult question whether such sanctions do in fact prevent such conduct. See H. Packer, The Limits of the Criminal Sanction 35-70 (1968); F. Zimring \& G. Hawkins, Deterrence 249-338 (1973).

"See, e.g., FTC's complaint against Sears, Roebuck \& Co., N.Y. Times, July 11, 1974 , at 41 , col. 4 . 
luctance to define particular businesses as members of a "hardcore" of serious offenders. Like other white-collar criminals, the offenders simply do not seem like "outsiders," and the offenses do not seem significantly different from acceptable conduct. The community does not appear to take such offenses as seriously as other types of deviance, and the law enforcement response does not have the vitality that it has in other areas. Thus, most states have enacted few criminal penalties for consumer fraud. Even where criminal penalties do exist they are seldom used. There is, in short, a reluctance to define the situation in terms of serious deviance and to respond solely with law enforcement. ${ }^{6}$

It is not surprising that the issues take on quite another character when viewed from the perspective of the consumer. The law enforcement response to consumer grievances adopts the somewhat aloof perspective of the lawmaker, the law enforcer, and society as a whole. The consumer who feels that he has been treated unfairly may be angry and outraged at the conduct of the seller, and may demand that action be taken against him, but his primary objective is to get help with his problem and to obtain what he thinks is his due. In other words, the consumer focuses on his private interest in the dispute-his own problem-not on the fact that the businessman may have acted deviantly-which is society's problem. The consumer is usually more interested in restitution than in retribution.

When consumers with concrete grievances approach a third party, they are generally seeking help with their private disputes. If the institution is to respond directly to the consumer as its client, it must adopt a stance toward the conduct of the business very different from that of law enforcement. This alternative response to consumer grievances is dispute settlement. It focuses not on the deviant normative quality of the seller's conduct, but on the concrete dispute presented by a dissatisfied buyer, on his injury, and on what can be done about it. It is victim-oriented; it responds to the consumer's private

\footnotetext{
${ }^{6}$ Professor Caplovitz has commented on the New York Consumer Frauds Bureau: "To my knowledge not a single businessman in New York has been put in jail for cheating his customers." Hearings on H.R. 11601 Before the Subcomm. on Consumer Affairs of the House Cornm. on Banking \& Currency, 90th Cong., 1st Sess. 664 (1967), quoted in Kripke, Gesture and Reality in Consumer Credit Reform, 44 N.Y.U.L. REv. 1, 44 n.183 (1969). See also National Institute for Consumer Justice, Criminal Sanctions in CoNstimer Legislation 379-402 (Staff Study VI, 1972).
} 
interests in the dispute rather than the separate interest of the state in law enforcement.

To take another example of vacuum cleaner buying, suppose that $X$ complains that store $Y$ advertised a "top quality vacuum cleaner at the amazing low price of $\$ 39.99$," that he bought the machine, which broke down two weeks later, and that $Y$ refused to repair or replace it without expense to $X$. From the dispute settling perspective, one's response is to determine who is to bear the loss and how the injury can be minimized and remedied. The dispute settlement response does not look outside the single dispute to see if there are patterns of business practice that ought to be condemned; it concentrates instead upon obtaining a satisfactory resolution or adjustment of the single dispute. This point is illustrated by the fact that the two examples given above may have been purchases of vacuum cleaners from the same seller in response to the same advertisement. Identifying and labeling business practices as fraudulent is an approach to the situation different from trying to settle each complaining customer's dispute, and leads to different results.

These two stances may be understood as the criminal and civil perspectives of the legal system. ${ }^{7}$ The state has a special independent interest in ensuring that conduct defined as criminal is met with official negative sanctions. This interest is based upon maintenance of the moral consensus and morale of society and upon deterrence. These public interests of the state are separate from the private interests of the parties to the dispute. The state also has an interest in promoting the just and satisfactory resolution of private disputes, whether or not its separate public interests are asserted simultaneously. The proper relationship between these two stances is both a complex jurisprudential issue and a pressing practical problem of priorities and institutional design.

This Article addresses the problem of responding to consumer grievances on several levels. The theoretical background is discussed in Section I. This is intended as an approach to a theory of dispute management institutions; I shall sketch a general model applicable to disputes in general, exemplified in

\footnotetext{
i In some contexts this dichotomy appears between regulatory and dispute settling functions. See, e.g., Whitford \& Kimball, Why Process Consumer Complaints? A Case Study of the Office of the Commissioner of Insurance of Wisconsin, 1974 WIs. L. REv. 639.
} 
terms of disputes concerning consumer transactions. The goal of this general discussion is to set what then follows in the context of the array (one hesitates to call it a system) of institutions which play a part in the function of dispute management. Sections II, III, and IV focus on a case study of a consumer fraud bureau. Section II describes the bureau and our in-depth study of it. Sections III and IV focus on two aspects of the bureau: who complains to the bureau about what, and the bureau's response to these complaints. Section V attempts to place the functioning of the consumer fraud bureau in a more general context.

\section{Theoretical Background}

Law functions both at the abstract preventive level by creating and announcing rules of conduct and at the concrete level by ameliorating disputes and solving specific problems. Llewellyn and Hoebel have written:

Law has as one of its main purposes to make men go round in more or less clear ways . . . to channel behavior in such manner as to prevent or avoid conflict....

But there is more to law than ... regulation and prevention. Law has the peculiar job of cleaning up social messes when they have been made. Law thus exists also for the event of breach of law and has a major portion of its essence in the doing of something about such a breach. ${ }^{8}$

The criminal law may be seen as stating the most important norms of the society, the absolute limits of behavior which will be tolerated, the normative boundaries of the community. It is the business of the criminal law not only to set these limits, but also to police these boundaries by law enforcement and punish those who venture out past the limits, defining them as deviant "outsiders" in order to dramatize the line between acceptable and unacceptable conduct. ${ }^{9}$

But even within the absolute boundaries of acceptable conduct, disputes arise and must be resolved. There are thus rules

\footnotetext{
${ }^{8}$ K. Llewellyn \& E. Hoebel, The Cheyenne Way 20 (1941).

"For a lucid discussion of the boundary-maintaining function of the criminal law, see K. Erikson, Wayward Puritans, Ch. 1 (1966). For other general discussions of the functions of criminal laws, see J. Andenaes, Punishment and Deterrence (1974); H. PACKER, supra note 4, at 9-61; F. ZimRing \& G. Hawkins, supra note 4, at 74-90.
} 
of varying degrees of generality channeling acceptable conduct to avoid disputes and setting out the proper resolution of disputes when they do arise. All of these levels of rules are implicit in Fuller's characterization of law as the "enterprise of subjecting human conduct to the governance of rules."10

The rules of law are followed to a substantial extent without explicit application of the force of the state. But when an active dispute arises, various institutions may be called forth to resolve it. Institutions responding to disputes range from official law courts to individual self-help, with a variety of public and private community resources in between. What all of these institutions have in common is that they respond to disputes when called into operation by a perceived breach of the rules of lawa "trouble-case," as Llewellyn and Hoebel term it. ${ }^{11}$ From the dispute settlement perspective, these institutions may be analyzed, as Abel suggests, as a range of interveners into disputes. ${ }^{12}$

It may be useful to conceptualize this array of dispute management institutions as arranged on a continuum, with the two functions of law set out by Llewellyn and Hoebel as its end points. At one pole of the continuum (top of Figure I) is the function of creating and announcing rules of law to channel and regulate behavior so as to prevent dispute. The products of this social function are the abstract rules of law, the authoritative statement of the legal norms of the society. The most prominent institutions which carry out this rulemaking function are legislatures, although it also is carried out by adjudicative, administrative, and executive bodies of government, and by the rulemaking bodies of private organizations. ${ }^{13}$ I shall call this pole of the continuum the "formal" pole to indicate that the functions, products, and institutions at this end are those usually associated with the formal law and legal institutions of the society; they tend to be more formal in the sense of logical pre-

${ }^{10}$ L. Fuller, The Morality of Law 74 (1964).

${ }^{11} \mathrm{~K}$. Llewelly \& E. Hoebel, supra note 8, at 22.

${ }^{12}$ Abel, A Comparative Theory of Dispute Institutions in Society, 8 LAw \& Soc. REv. 217 (1974). Abel suggests that characteristics of dispute intervention process ought to be seen as continuous variables, not as either/or models. Id. 232-39.

${ }^{13}$ For a discussion of the multiplicity of legal levels and legal systems.in society, see M. Weber, Wirtschaft und Gesellschaft (1921), reprinted in part in M. RheinStein, Max Weber on Law in Economy and Society (1954); Evan, Public and Private Legal Systems, in LAw AND Socrology 165 (W. Evan ed. 1962); Pospisil, Legal Levels and Multiplicity of Legal Systems in Human Societies, $11 \mathrm{~J}$. Confl. Resolutron 2 (1967). 
cision, official authoritativeness, and fixed procedural routine. At the other end of the continuum, the "informal" pole, is the function of problem solving-doing something about specific disputes on an ad hoc basis. Just as the abstract statement of rules is intended to channel all behavior in general but not to resolve any particular disputes, problem solving functions to resolve particular disputes and normally does not result in the statement or creation of rules. The products of the problemsolving function are resolved concrete problems; such concrete resolutions need leave no mark on the normative structure of rules. The purest form of this process is the problem solving activity of the individual who has the grievance. A vast array of informal problem solving institutions exists, some organized and others not, some solving problems as their main activity, others doing so only peripherally. Such institutions range from public community resources (for example, police, social casework agencies, action lines, ${ }^{14}$ Better Business Bureaus, lawyers acting informally) to almost anyone to whom another might turn for help with a problem (for example, friends, relatives, business associates, politicians, ${ }^{15}$ ministers, doctors, and employers).

Between the formal and informal poles is arranged a variety of dispute management institutions, some of which are set out in Figure $I$ with their functions and products. (I do not mean to enter the continuing debate over which institutions are to be considered legal institutions. ${ }^{16}$ ) Many disputes which could be resolved by the explicit, relatively formal legal institutions are in fact resolved by much less formal problem solving institutions. It is this commonality of function that forms the basis for consideration of these informal institutions on the same continuum as explicitly legal institutions.

Toward the informal pole, the problem solving process predominates. Parties to problems or disputes work them out with such help as they seek. No rules or procedures structure the fluid give-and-take of the situation, and no rules or formal

${ }^{14}$ Mass media action lines indeed define themselves in terms of informality and problem solving. One newspaper serving most of Illinois states: "The Action Line solves problems, gets answers, cuts red tape, investigates complaints, and stands up for your rights." Chicago Today, May 23, 1972, at 8.

${ }^{15}$ See, e.g., I R. Nader Congress Project, Report on Ronald V. Dellums, Dem. Rep. From Cal. 17, in Citizen's Look at Congress (1972); VII id., Report on William A. Barrett, Dem. Rep. From Pa. 1-2. See also E. O'Connor, The Last Hurra h 11-16 (1955).

${ }^{16}$ See, e.g., Fuller, supra note 10, at 110. 
precedents result from the outcome. The resolution need not be evaluated normatively as long as the dispute is terminated. As one moves away from this pole toward the formal pole, the third-party presence (usually the state) increases, the formal rules and procedures of law play a greater role, and the process of applying, deciding, and announcing fixed rules increases in importance relative to the problem solving process. As one moves further in the direction of the formal pole of the continuum, the flexibility and particularity of concentrating on concrete disputes and their resolution gives way to the application of fixed norms to disputes.

The ideal of the common law process occupies a self-conscious midpoint on the continuum, attempting at once to emphasize concrete dispute resolution and rulemaking decisions that create precedents. The common law's resolution of concrete disputes often involves the application of existing general rules that do not seem completely appropriate to the individual dispute; on the other hand, common law precedents often seem to be a patchwork of statements of rules designed to settle particular atypical disputes and thus seem not to form a coherent set of abstract rules to channel behavior. The tension generated by hewing to this middle course illustrates the divergent dispute management processes I have described as a continuum.

As one moves past the model of the common law courts toward the formal pole, the concrete problem-solving function begins to drop out entirely, to be replaced by the processes of fashioning and communicating general rules. The approach to the task of dispute management shifts from the amelioration of present disputes to the prevention of future disputes.

One further feature of the continuum is important to the consideration of the management of consumer disputes. Increased formality carries with it increased resource requirements. Informal dispute resolution involves only the immediate dispute. Only as much time and other resources as are required to resolve that problem need be expended on the particular dispute. More formal problem resolution involves other disputes as well (those which will be resolved or prevented by the precedent established by the outcome of this dispute) and hence demands more resources to fashion appropriate general rules. A direct negotiation with a store or a call to a friend who works 


\section{FIgURE I}

The System of Dispute Management Institutions
Function
Product
Institutions

"Formal" Preventive

rule creation and announcement

rule dramatization, illumination of normative boundaries

application of general rules to cases and elaboration of rules

termination of conflict by rule application

mediation, facilitation of bargaining to resolve disputes

direct bargaining to settle disputes abstract, general rules of conduct, law

criminals, "outsiders" as dramatic examples of deviance and its consequences

reasoned court opinions, common law precedent

adjudicated, decided disputes

settled disputes, bargains, compromises concrete problems solved

\section{Legislation}

Administrative rulemaking prosecutors, law enforcement agencies, criminal courts

appellate courts civil courts, arbitration, administrative hearing boards pretrial conferences, mediation services, community helping resources-e.g., legal aid, Better Business Bureaus, action lines, consumer fraud bureaus, complaint handling by regulatory agencies private bargaining by individual with problem-grierance

"Informal" problem solving 
at the store to request help with a dispute usually involves little time, little energy, and no fees, additional manpower, or other specialized resources. The use of a neighborhood pro se small claims court or arbitration board (where such things are available) requires more resources-preparation of some papers, organization of receipts and arguments, attendance at a hearing, and the strain of stating and arguing the case. In addition, judges and places to hold the proceedings are required. Common law courts and administrative tribunals require still more resources from the litigants and from the dispute resolution institution. Litigants require lawyers, complex documents, witnesses, and filing fees. The investment of time spent in hearings and preparation of cases increases. Hearing rooms must be larger to accommodate the public, additional court personnel, parties, lawyers, and witnesses (hence specialized courthouses and hearing rooms emerge). The adjudicators must often issue written opinions, requiring further time and resources for specialized professional judges, law clerks, clerical help, and the publication and retrieval of opinions. The mobilization of legislative solutions to problems requires even more resources-gaining the support of segments of societal power, lobbying, committee hearings, staff reports, the time and salaries of whole legislatures and their staffs. Such increasing resources are congruent with the broadening focus and impact of the more formal processes and their products.

The heavy investment of resources required to use formal institutions to resolve disputes creates a pressure to resolve them by more informal means; the continuum therefore defines the typical sequence of resources used in the course of attempting to resolve a dispute. One may appeal the unsuccessful outcome of direct negotiations to one community resource, then to another, and finally to a court. Or one may not appeal, but simply "lump it" when the required resource investment becomes too large relative to the subjective importance of the dispute. In this manner, the eclectic assortment of institutions and resources that are actually used in the course of trying to solve a problem or settle a dispute are interrelated to form a loosely organized system of dispute settlement resources which may be seen as a part of the more encompassing system of dispute management institutions.

Informal institutions require fewer resources to handle a single dispute since they dispense with the rulemaking func- 
tion; but informal institutions are more efficient to the society as a whole (fewer resources may resolve the same number of disputes) as well as to the party with the problem. ${ }^{17}$ More formal institutions address behavior on a macro-level by stating general rules which, to the extent they are followed, may prevent numerous disputes; yet they provide little concrete micro-problem-solving capacity to handle active disputes.

As the case study of a consumer fraud bureau is discussed, it will become apparent that the bureau operates at several different levels of the continuum. What I have referred to as the law enforcement stance of the bureau describes its functions in the more formal portion of the continuum. The bureau is a part of the formal machinery of government-a division of the state attorney general's office-and has formal law enforcement authority. Yet as it functions as a community resource to help consumers who complain to it and to resolve their disputes, the bureau acts informally, largely without stated rules or powers, and independently of its statutory law enforcement powers. Thus the bureau also functions in the more informal portion of the continuum, nearer the problem-solving pole.

\section{The Consumer Fraud Bureau}

This Article is based upon the detailed examination of one consumer fraud bureau of the Illinois Attorney General's Division of Consumer Fraud and Protection. The office (hereinafter called "the Bureau") ${ }^{18}$ examined in detail is located in the downtown business area of a major city in Illinois and serves the metropolitan area of that city.

Consumer fraud bureaus are generally divisions of state attorneys general's offices. They exist in many states and have

${ }^{17}$ Efficiency in resource use is often accompanied by what may be seen as arbitrariness and dispute outcomes which do not conform to legal rules (justice). Informal institutions are characteristically controlled by party bargaining rather than by objective decision, and disputes, therefore, terminate when both parties grievances are reduced below the threshold level at which they will take action on them, whether or not the facts have been ascertained or the outcome arranged in accordance with legal norms. Informal outcomes may be arbitrary witl respect to the applicable legal rules and inconsistent with each other-achievement of these goals would require additional resource use. Consistency and rule conformity are more characteristic of the less resource-efficient, more formal dispute settlement institutions.

${ }^{18}$ One of the conditions for gaining access to Bureau files and hearings, which are not generally accessible to the public, was that the location of the specific office of the Consumer Fraud and Protection Division examined in detail not be stated. 
powers roughly comparable to the one studied in depth. ${ }^{19}$ They are created as law enforcement agencies and are granted investigatory and prosecutorial powers to prevent certain proscribed business practices. The title of the empowering statute of the bureau which we studied sets as its purpose "to protect consumers and borrowers against fraud and certain other practices by or on behalf of sellers and lenders of money and to give the Attorney General certain powers and duties for the enforcement thereof."20 The main operative provision of this Consumer Fraud Act declares:

The act, use or employment by any person of any deception, fraud, false pretense, false promise, misrepresentation, or the concealment, suppression, or omission of any material fact with intent that others rely upon such concealment, suppression, or omission, in connection with the sale or advertisement of any merchandise, whether or not any person has in fact been misled, deceived or damaged thereby, is declared to be an unlawful practice .... ${ }^{21}$

The Act goes on to declare certain other more specific acts to be unlawful practices ${ }^{22}$ and grants the following broad enforcement powers:

Whenever it appears to the Attorney General that a person has engaged in, is engaging in or is about to

19 See NAAG Report, supra note 2, at 420; National Association of Atrorneys General, State Programs for Consumer Protection 17-29 (Aug. 1972); Eovaldi \& Gestrin, Justice for Consumers: The Mechanisms of Redress, 66 Nw. U.L. REv. 281, 299-302 (1971); Rice, Remedies, Enforcement Procedures and the Duality of Consumer Transaction Problems, 48 B.U.L. REv. 559, 583-93 (1968); Developments in the Law -Deceptive Advertising, 80 HARv. L. REv. 1005, $1124-34$ (1967); Comment, Translating Sympathy for Deceized Consumers into Effective Programs for Protection, 114 U. PA. L. REv. $395,430-34$ (1966).

The particular bureau studied is one of the best financed and staffed in the country. See National Association of Attorneys General, Appropriations and Compensation table 3.54B (Feb. 1972); NAAG RePort, supra note 2, at 417-18; National Association of Attorneys General, State Programs for Consumer Protection 11-13 (Dec. 1973); National Association of Atrorneys General, State Programs for Consumer Protection 17-18 (Aug. 1972). It is also one of the few bureaus that claims to handle all complaints received. Id. 41 .

${ }^{20}$ Act of July 26, 1967, § 2, [1967] Ill. Laws 2143 (now ILL. ANn. STAT. ch. 1211/2, § 261 (Smith-Hurd Supp. 1974)). The Consumer Fraud Act was substantially amended effective October 1, 1973, and became the Consumer Fraud and Deceptive Practices Act (Ill. Ans. Stat. ch. 1211/2, §§ 261-72 (Smith-Hurd Supp. 1974)). The Consumer Fraud Act is quoted here as it was in force during 1972, the year for which Bureau activity is examined.

${ }^{21}$ Act of July 24, 1961, § 2, [1961] Ill. Laws 1867 (now Ill. ANN. Stat. ch. 1211/2, $\S 262$ (Smith-Hurd Supp. 1974)).

${ }^{22}$ See Ill. Ann. Stat. ch. 1211/2, §§ 262A-M (Smith-Hurd Supp. 1974). 
engage in any practice declared to be unlawful by this Act he may seek and obtain in an action in a Circuit Court an injunction prohibiting that person from continuing those practices or engaging therein or doing any acts in furtherance thereof ....

The court may make such orders or judgments as may be necessary to prevent the use or employment by a person of any prohibited practices, or which may be necessary to restore to any person in interest any moneys or property, real or personal, which may have been acquired by means of any practice in this Act declared to be unlawful including the appointment of a receiver or the revocation of a license or certificate of registration authorizing that person to engage in business in this State or both in cases of substantial and wilful violation of this Act. ${ }^{23}$

Although such bureaus are legislatively defined as law enforcement agencies, they often in fact have adopted a dispute settlement stance of informally helping consumers to solve their problems with sellers that has all but supplanted their formal law enforcement activities. What may have started as a process of investigation of complaints and other information to determine whether cases warrant prosecution has evolved into something quite different-the mass processing of individual consumer-seller disputes. The function of dispute resolution has taken on a life of its own quite independent of the law enforcement function. The law enforcement activities of the bureaus are related only tenuously to the dispute settling process. The National Association of Attorneys General says of the choice between prosecution and complaint handling:

Once the legislative framework for consumer protection has been established, questions of administrative policy remain. States differ in the relative emphasis they give to handling individual complaints or to preventing deceptive practices. Some states stress records of recoveries ....

Other administrators contend that a good consumer fraud program must involve both restitution to individual complaints and the prosecution of offenders. ${ }^{24}$

${ }^{23}$ Act of Sept. 6, 1968, § 1; [1968] Ill. Laws 410 (now IlL. ANs. STAT. ch. 1211/2, $\S 267$ (Smith-Hurd Supp. 1974)).

24 NAAG REPORT, supra note 2 , at 411. 
This ought not to be thought of as a simple question of "administrative policy" to be decided on the basis of prevailing notions of what would be a "good consumer fraud program." Rather, complaint handling and prosecution are separate modes of response to consumer complaints which arise out of divergent ways of perceiving and defining consumer problems. The dispute settlement and law enforcement stances are fundamentally incompatible in assuming divergent definitions of consumer grievances and in leading to different types of reaction.

Data were collected from several sources in order to determine how the Bureau approaches and carries out its functions.

First, complaints received by the Bureau and their disposition were analyzed. A systematic sample, every twentieth case of the total of 9015 Bureau complaints, was selected for analysis. The resulting sample of 449 files was drawn from complaint files closed by the downtown office in 1972 .

The sample complaint files were coded by two coders and the data were prepared for and analyzed by a 370 IBM computer. ${ }^{25}$ In addition to the sample of complaint files, we examined all litigation files which involved any complaint file in the sample, thirty-four in all. Litigation files typically involve multiple complaints against a single business. The inclusion of one of the complaint files in the sample in a litigation file selected the entire litigation file for study. The sample of litigation files appears fairly representative when compared to the Bureau's overall litigation docket records.

Second, in order to determine the reliability of our inferences from the complaint files, to determine the impact of $\mathrm{Bu}$ reau action on the disputes, and to gain some further understanding of the underlying disputes, we interviewed a sample of complainants on whose complaints the Bureau had acted.

The validity of much of the information collected from the files was verified by means of selected interviews with complainants. In most cases the interviews confirmed the file information and our interpretation of the facts of the complaint and the attitudes and actions of the parties. With respect to use of prior resources, communication and bargaining between the parties before complaint to the Bureau, the complainant's de-

2.- The intercoder reliability was evaluated on the basis of a subsample of 20 files coded by each coder and the author. The overall agreement on the coding of these 20 files among the three (two coders and the author) was $85 \%$. 
sire for a public-oriented (punitive) remedy, and his perception of the seller as dishonest or fraudulent, the interviews supported our inference that the omission of any mention of these facts in the complaint usually indicated that they had not in fact occurred.

Although we were initially granted permission to interview "anyone we wanted to" among the complainants and businessmen, this permission was drastically limited as the time to conduct the interviews approached. Permission to interview businessmen was withdrawn, and the Bureau insisted that it telephone complainants itself to obtain their consent to be interviewed before we contacted them. Because of this constraint, the number of interviews had to be severely reduced. Since we were interested primarily in understanding the impact of Bureau action on disputes, only complainants in whose cases the Bureau had successfully contacted the business complained against were selected. We also limited our interviews to complainants residing in the metropolitan area. The low proportion $(35 \%)$ of complainants contacted within the limited sample selected for interviews resulted from the Bureau's lack of persistence in contacting complainants for our interviews. (The task was assigned to one already busy Bureau secretary.) Although the proportion of complainants contacted was unfortunately low, I am reasonably sure that there was no systematic bias in terms of the substance of the matter or the identities of the parties involved.

Ultimately, interviews were obtained with a total of 42 complainants $(32 \%)$, out of a total of 131 complainants with whom contact was attempted. Six complainants (5\%) declined to be interviewed, three explicitly, three by repeated delay or evasion. The balance of the complainants could not be contacted, either because no current telephone number could be obtained $(19 \%)$ or because no answer could be obtained to telephone calls (44\%). Our conclusions from the interview data are thus impressionistic and not quantitatively conclusive.

Third, I observed 40 informal Bureau hearings on individual complaints. These hearings concerned current cases, not cases included in the complaint sample-all of which were closed. Such hearings normally are closed to the public, with only a Bureau hearing officer, the complainant, and the representative of the business (and occasionally its lawyer) present. At 
those hearings which I attended I was introduced as "a lawyer," or "an observer," or, in many cases, not introduced at all. Because none of the parties had been to a Bureau hearing before, each was unaware that the presence of an observer was out of the ordinary. I doubt that my presence at the hearings significantly altered party behavior. I am less sure about its effect on the conduct of the hearing officers; I was present with the express approval of the chief of the Bureau and my affiliation with an outside research organization was known. My reasons for thinking that the hearings I observed were fairly typical are based on the similarities among what I observed at different hearings, the written reports of prior hearings in the files, and the impressions of complainants given during interviews as to the conduct of the hearings and their outcomes.

Fourth, during the course of several months, I had interviews and discussions at various levels of formality with substantially all of the staff of the Bureau. In addition, I had a chance to observe fairly unobtrusively the intake process, initial interviews with complainants, and staff discussions of cases, and generally to get the "feel" of the Bureau and its staff. During this time, I had many discussions with complainants, businessmen, and lawyers present for hearings or to file complaints. This informal information forms the background of the case study and of the analysis of the statistical data.

\section{The Complaints to the Bureau}

When consumers feel unfairly treated by retail businesses, they often complain to and seek help from community resources. ${ }^{26}$ As Caplovitz ${ }^{27}$ and Levine and Preston ${ }^{28}$ have demonstrated, knowledge of available community resources is limited, and actual use of resources is even more severely limited within groups known to have many consumer problems; but for those consumers who have the knowledge, the perseverance, and the presence of mind, ${ }^{29}$ there are many community resources

${ }^{26}$ The words "business" and "seller" as used in this Article include providers of services as well as of goods. Unless otherwise indicated, I do not mean to distinguish between goods and services.

${ }^{27}$ D. Caplovitz, The Poor Pay More (1967).

${ }^{28}$ Levine \& Preston, Community Resource Orientation Among Low Income Groups, 1970 WIS. L. REv. 80.

${ }^{29}$ See J. Garlin, J. Howard \& S. Messinger, Civil Justice and the Poor 61-76 (1967) (speaking of "legal competence" as the defining and defending of one's legal rights); Friedman, The Idea of Right as a Social and Legal Concept, $27 \mathrm{~J}$. Soc. Issues 
which intervene and provide varying amounts of help. In this section, I shall analyze those consumers who came to the consumer fraud bureau for help-who they were, what they complained about, what they wanted, and what they did before coming to the Bureau. In many cases the Bureau intervened; the process and outcome of Bureau intervention will be discussed in Section IV.

\section{A. Who Complained}

Although consumer fraud primarily affects the poor minorities, ${ }^{30}$ it is mostly the white middle class who complain to the Bureau. The poverty level for a family of four in 1969 in the standard metropolitan statistical area (SMSA) in which the Bureau operates was $\$ 3,743 .^{31}$ Seven percent of families in the SMSA were below the poverty line. In our sample of complainants, only one percent had incomes below $\$ 4,000$ (an income level somewhat above the poverty line). Thirty-one percent of the SMSA population had incomes of more than $\$ 15,000$, while in the sample only $15 \%$ did. Thus, both extremes of income level are underrepresented among Bureau complainants. The proportion of families with median incomes between $\$ 10,000$ and $\$ 15,000$ in the SMSA was $32 \%$, whereas in the sample it was $62 \%$.

The relative absence of both extremes of wealth from Bureau complainants is striking. One might speculate that the absence

189, 190-92 (1971) (speaking of the concept of "rights consciousness"). These are among the intangible elements of personality which condition the use of resources in problem solving.

${ }^{30}$ See, e.g., D. Caplovitz, supra note 27; The Law and the Low Income Consumer (S. Katz ed. 1968); W. Magnuson \& J. Carper, The Dark Side of the Market Place 32.58 (1968); $c f$. S. Margolis, The Innocent Consumer v. The Exploiters (1967); see also Hearings on National Consumer Protection Before the FTC (1968); Joint Hearings on S. $707 \&$ S. 1160 Before the Subcomm. on Reorganization, Research E International Organizations of the Sen. Comm. on Gov't Ops., and the Subcomm. on Consumers of the Sen. Comm. on Commerce, 93d Cong., 1st Sess. (1973).

${ }^{31}$ Poverty level data from U.S. Census Bureau, 1970 Census of Population \& Housing, Census Tragts [City], Ill., Standard Metropolitan Statistical Area, pt. 2, App. B, p. App. 8 (1972). For complainants in the sample our method of approximating complainant income was to locate the census tract in which the complainant resided and then determine the median family income for that tract. The small size and homogeneity of census tracts indicates that the approximation is relatively good. Still the approximation does not take account of the fact that incomes within the same tract vary from the median income of the tract, or that it is the income of families that is being used and no adjustment is made as to size of family of the complainant (a fact we do not know). Information is based on the 1970 Census, which used 1969 income data. 
FIGURE II

Income Distribution of Bureau Complainants and of SMSA Population ${ }^{32}$

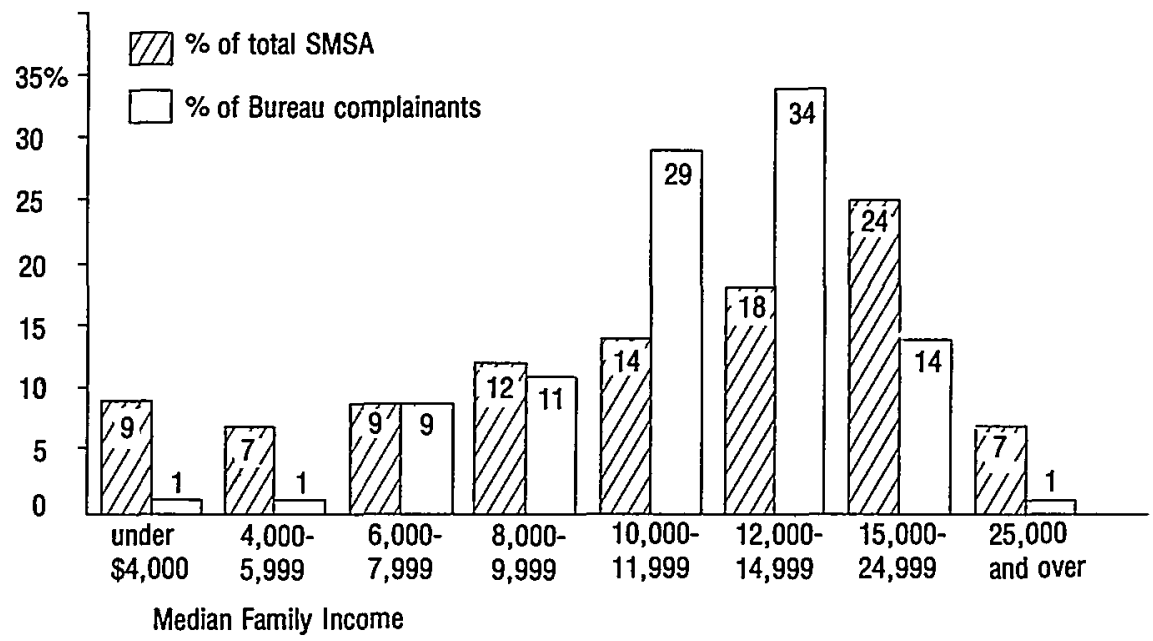

of poor complainants results from their lack of knowledge of or confidence in problem-solving resources available in the community. It also might be explained in terms of a reluctance to assert grievances resulting from habits of subservience and passivity or from low expectations of success in dealing with government officials. The consequence of these factors may frequently be a passive acceptance of one's problems as the effect of fate, misfortune, or oppression, rather than a more self-confident conceptualization of problems as individual grievances which can be dealt with. Thus, the poor, one might speculate, are short on what has been termed "legal competence."33 The absence of the higher income individuals from Bureau complainants may result from very different causes. Higher income persons are thought to have more of that congeries of characteristics and habits called "legal competence," including more knowledge of resources, experience and skill in using them,

${ }^{32} \mathrm{~N}=334$. This is $92 \%$ of the 367 who resided in the SMSA. Due to the methodology employed, note 31 supra, income could be approximated only when the census tract in which the complainant resided could be identified. This could be done in only 336 cases. Income data were unavailable for two identified census tracts. Total SMSA data are from U.S. Census Bureau, supra note 31 , pt. I at P-355.

${ }^{33}$ See J. Carlin, J. Howard \& S. Messinger, supra note 29, at 81. 
money to hire them, and more contacts and friendships-more influence-with which problems can be solved without the use of organized resources. In addition to this relative abundance of means to solve problems, the patterns of purchasing are quite different among the wealthier. The "better" stores which charge the full undiscounted price may be, in effect, selling problemsolving services with the merchandise so that their higher income customers do not often have to go elsewhere to take care of problems.

As Table I indicates, the Bureau's complainants were predominantly white. The white complainants had significantly higher incomes than the black complainants. Although $64 \%$ of black complainants had incomes under $\$ 8,000$, only $2 \%$ of whites did. Conversely, $26 \%$ of white complainants had incomes over $\$ 15,000$, while no blacks did. ${ }^{34}$

TABLE I

Race of Bureau Complainants and Population of SMSA ${ }^{35}$

\begin{tabular}{lcc}
\hline Race & $\begin{array}{c}\text { Percentage of } \\
\text { Bureau Complaints }\end{array}$ & $\begin{array}{c}\text { Percentage of } \\
\text { Total SMSA }\end{array}$ \\
\hline White & 88 & 82 \\
Black & 12 & 18 \\
& $100 \%(\mathrm{~N}=285)$ & $100 \%$ \\
\hline
\end{tabular}

Fifty-nine percent of the complainants were men. Although $64 \%$ of the white complainants were men, only $43 \%$ of the black complainants were men.

It might be suggested that the lower frequency of complaints from women, blacks, and lower income people results in part from the increased difficulty for these groups of physical access

${ }^{34}$ Income level information is based on median family income for an entire census tract, see note 31 supra. This may distort the analysis of income by race: for example, it may be the case that there are blacks with incomes of over $\$ 15,000$ in the sample but that they were not coded as black because they live in integrated census tracts. See note 35 infra.

${ }^{35}$ Race was determined on the basis of the aggregate racial characteristics of the census tract in which the complainant resided. Complainants residing in tracts which were $4 \%$ or less black were coded as white (252), those in tracts with $95 \%$ or more black were coded black (33), those residing in tracts of neither description were coded as unknown (51). The racial breakdown of complainants is based on 336 complainants; census tracts for other complainants could not be identified, see note 32 supra. Total SMSA data are from U.S. Census Bureau, supra note 31, pt. I at P-1. 
to the downtown Bureau office. This does not appear to be the case, however. We know that $45 \%$ of the complaints were filed on Bureau forms and the other $55 \%$ by letters. Although we do not know what proportion of the complaints made on forms were made in person at the Bureau's office (some were made on forms mailed to complainants), we do know that those complaining by letter did not complain in person and thus were not deterred by the trip downtown. A higher proportion of women, whites, and higher income individuals complained by letter than of men, blacks, and lower income individuals. Whether others were deterred we do not know. It ought also to be pointed out that the act of filing a complaint remotely and impersonally by letter may itself be an aspect of "legal competence" and sophistication in dealing with bureaucratic organizations that might explain the higher proportion of letter complaints among the whites and higher income groups.

The "party in interest" in the complaint was normally an individual or family. Ninety-six percent of the complaints concerned a transaction by an individual or household; only $3 \%$ involved businesses as complainants. The remaining $1 \%$ (only two complaints in our sample) were from other types of entities, one from a church group, the other from an employee complaining about the business practices of his employer. The relative absence of businéss complainants may indicate the existence of other problem-solving techniques and resources available to businesses. This clearly would be the case when the aggrieved business is a large customer of the seller.

Complainants generally present their own cases to the $\mathrm{Bu}$ reau. In $92 \%$ of the complaints in the sample, it was the person with the problem who made the complaint to the Bureau, in $4 \%$ a relative (usually for a minor child or an elderly parent), in $2 \%$ a lawyer for a client, and in $1 \%$, a consumer agency in another jurisdiction. In one case, an employee wrote for his employer who did not speak English; in another a minister wrote for his parishioner. Thus, the Bureau is primarily a pro $s e$ institution. That no specialized spokesmen are required and that the Bureau accepts informal letters illustrate the low "cost" to complainants of using the Bureau. This is consistent with the suggestion that informal problem-solving institutions require relatively low resource use. ${ }^{36}$

${ }^{36}$ See text accompanying notes 16-17 supra. 


\section{B. Who Was Complained About}

Small and moderate-sized businesses generated a disproportionate number of complaints relative to the volume of their business. Figure III compares the proportion of Bureau complaints which were made against businesses of different sizes with the sales volume of businesses of the same sizes for the United States as a whole. This comparison yields a rough notion of the size of businesses whose sales are complained about most often and, inferentially, whose sales most often generate grievances.

The largest businesses either generated fewer problems, or more often settled them through bargaining, or else the complaints were taken elsewhere than to the Bureau. Similarly, the larger businesses more often resolved complaints presented to them by the Bureau.

\section{Figure III}

Distribution of Bureau Complaints Involving Businesses of Different

Sizes Compared With Distribution of National Sales

Volume by Businesses OF DifFerent Sizes ${ }^{37}$

$D 7$-\% of total national sales volume by businesses of each size

$\square-\%$ of Bureau complaints involving businesses of each size

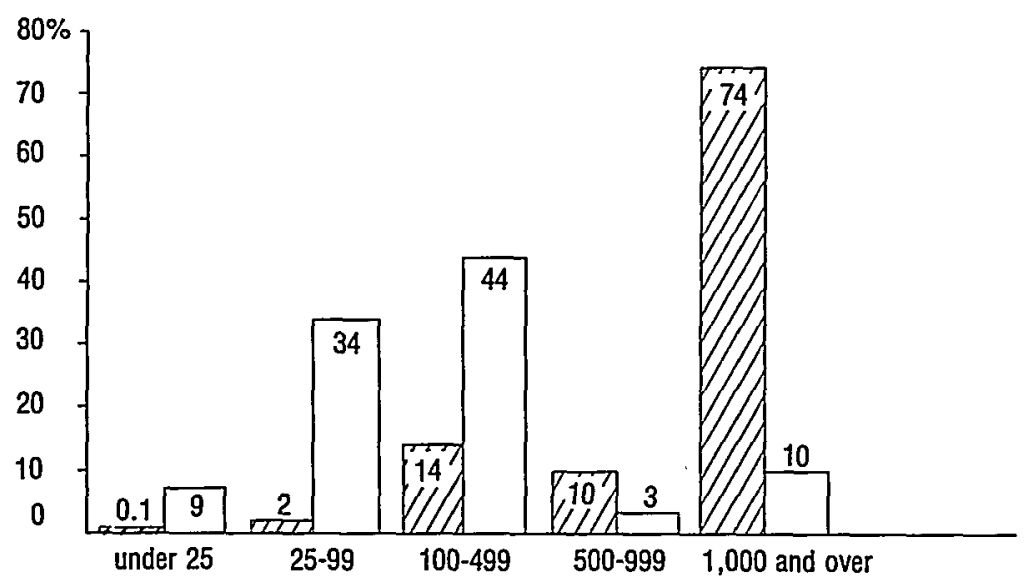

SIZE OF BUSINESSES (net assets in $\$ 1,000$ 's)

${ }^{37}$ Sales volume from U.S. Dep't of the Treasury, Internal. Revenue Service, Statistics of Income-1970, Business Income Tax Returns (1973). Net assets from 


\section{What Was Complained About-The \\ Underlying Transaction}

The complaints in the sample arose out of a tremendous variety of types of transactions. Table II compares the categories of consumer transactions generating complaints to the

TABLE II

Comparison of Distribution of Bureau Complaints with Distribution of National Consumer Expenditures for Types of Goods and Services ${ }^{38}$

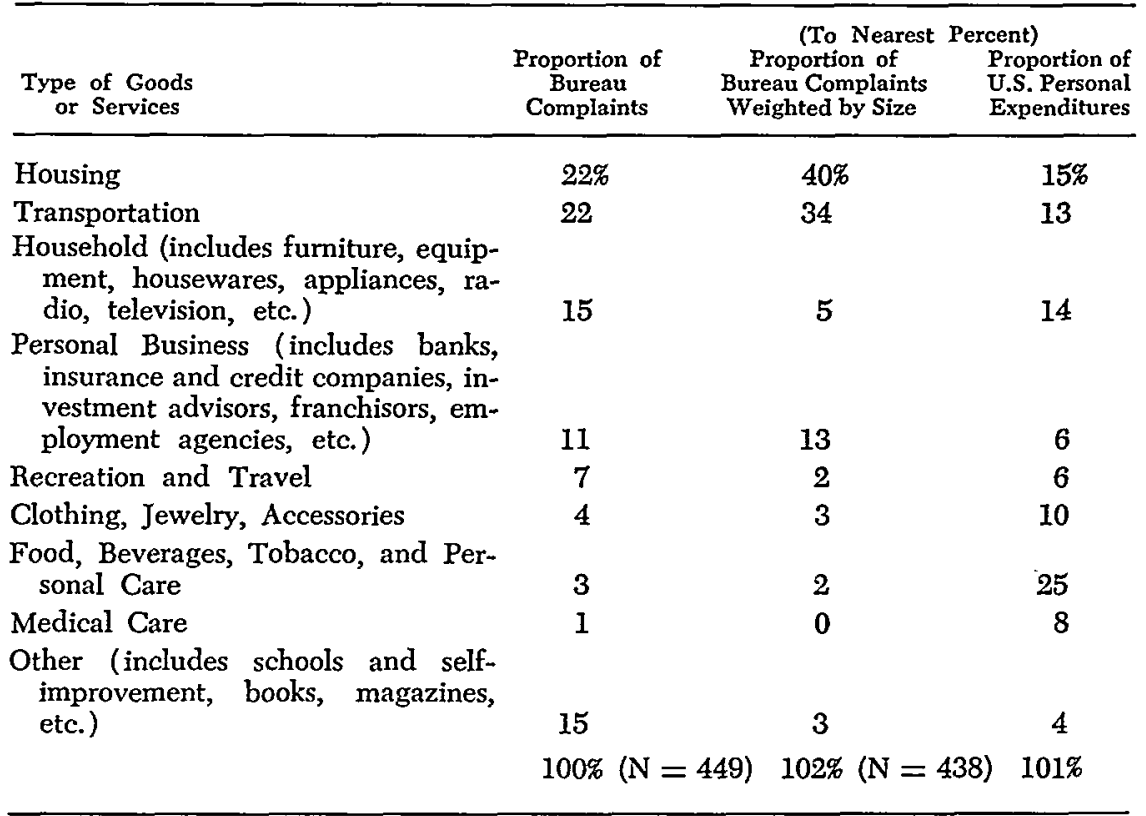

Dun \& Bradstreet, Middle Market Directory (1972), and Dun \& Bradstreet, Mirlion Dollar Directory (1972), and, for the categories under 25, 25-99, and 100-499, subjective judgments based on the contents of the Bureau files, including descriptions by complainants and Bureau personnel, number of branches, number of employees, pictures of business establishments, etc.

${ }^{38}$ Percentages for U.S. Personal Expenditures are from the 1970 column, rounded off, of Personal Consumption Expenditures, by Product 1950-70 in U.S. Census Bureau, 1972 Statistical Abstract of the U.S. 315. "Proportion of Bureau Complaints" refers to the proportion of the number of Bureau complaints in the sample involving each type of goods or services. "Proportion of Bureau Complaints Weighted by Size" refers to the proportion of the number of Bureau complaints in the sample involving each type of goods or services adjusted for the dollar amount of the transaction that generated the complaint. The adjustment was made by multiplying each complaint by the approximate dollar amount of the transaction underlying it and then recalculating the proportions of complaints involving each type of goods or services, with the resulting weighted complaint totals for each category. Complaints in which the dollar amount of the underlying transaction could not be determined are omitted. 
Bureau with expenditures for personal consumption, showing which areas of the retail consumer marketplace generate the most complaints relative to the volume of business. The first column of Table II shows the distribution of Bureau complaints in the sample arising out of transactions involving various types of goods and services. The second column shows the distribution of Bureau complaints arising out of transactions involving various types of goods and services weighted by the dollar amount of the underlying transactions. Column 3 shows the distribution of national consumer expenditures among the various types of goods and services. One can infer from comparing columns 2 and 3 in Table II that the disproportionately troublesome areas of the consumer economy are automobiles, housing (home construction and improvement, and central heating and air conditioning), and personal business. That housing is a troublesome area is understated, because national housing expenditure as shown in Table II includes all rents paid and the rental value of owner-occupied houses, as well as construction, improvement, and central systems. Complaints about schools and self-improvement courses made up almost half of the "other" category and seem disproportionately high. Complaints appear to arise disproportionately from consumer purchases where complex machinery or skilled labor is involved, and, as would be expected, less often where the typical item of purchase is very small, such as food.

The size of the transactions giving rise to complaints is interesting principally for its variation. As Table III shows, 30\%

TABLe III

Aalount of Transaction Giving Rise to Bureau Complaint ${ }^{39}$

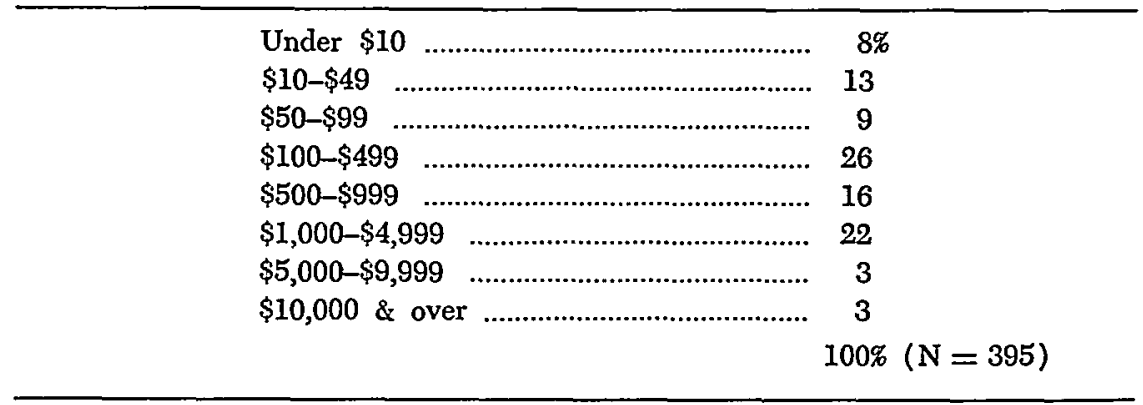

${ }^{39}$ Cases where the amount could not be determined (43) and where no transaction was involved (11) are omitted. 
of the transactions involved total amounts of less than $\$ 100$, and $6 \%$ involved amounts in excess of $\$ 5,000$. In smaller transactions, complainants tended to see the whole amount of the transaction as in dispute. In larger transactions, they defined the amount in dispute as a much smaller figure relative to the amount of the transaction.

The origin of the transaction-the situation in which the transaction was originally carried out-is crucial in characterizing the transactions giving rise to the disputes. The majority (82\%) of transactions involved purchases initiated by the buyer and made on a face-to-face basis, normally in the seller's store. In only $18 \%$ of these transactions was the seller's advertising mentioned by the complainant. One can infer that advertising was not a central factor in the balance $(64 \%)$ of the in-store transactions. Six percent of the complaints involved door-to-door sales, and $8 \%$ involved mail order sales. (Five percent could not be determined.)

This distribution is curious because consumer fraud has been reputed to involve door-to-door solicitation, deceptive advertising, or other seller-initiated contact and often to involve enticing misrepresentations, high pressure tactics, and getrich-quick schemes. This stereotypical consumer fraud involves a seller without an established place of business. But the complaints to the Bureau arise less out of such fraud situations than out of buyer-initiated purchases from a stable seller with a known place of business. The lack of congruence between the complaints received by the. Bureau and the stereotypes of consumer fraud begins to raise the question whether the complaints are properly thought of in terms of fraud. We have already discussed the widespread ambivalence in defining concrete transactions in terms of seller's deviant conduct (the law enforcement stance), or contractual breach, or even misunderstanding (the dispute settlement stance). This ambivalence in defining the situation will be observed again when the stance adopted by the Bureau in responding to consumer complaints is examined.

\section{The Grievance}

Almost all of the complaints concerned specific consumer purchases with which the buyer-complainant was dissatisfied. Each complaint was about an active current dispute between the complainant and a specific seller over a specific purchase transaction. The complaints were not generally about chronic 
conditions or general practices, such as high prices, poor quality or safety, sales practices, unavailability of goods, or credit or collection practices. Table IV shows the distribution of grievances stated by the complaints.

The largest group of complaints-30\%-concerned dissatisfaction with the service or product itself rather than with the practices of the seller. This group complained about specific defects in the products or services. An additional $18 \%$ concerned the failure of the seller to complete the transaction or to satisfactorily repair defective goods when he had agreed to do so. Thirteen percent were cases where the seller had done nothing at all to carry out the transaction. Thus, $61 \%$ of the complaints involved disputes about the substance of the transaction-the products and services themselves-and not deceptive sales practices, false promises, or price, credit, or other terms of sale.

TABLE IV

Prumary Grievance Stated by Complaints

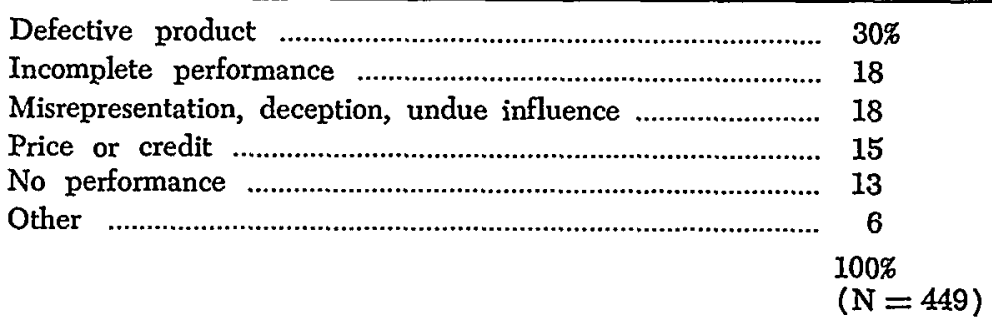

In $33 \%$ of the complaints the grievance involved conditions or practices of the seller rather than the product itself-in $15 \%$ the focus was on the price or terms of credit, and in $18 \%$ the primary complaint concerned misrepresentation, deception, or undue influence by the seller. Only when misrepresentation, deception, or undue influence was the sole primary grievance was the complaint included in that category in Table IV. Complaints giving primary emphasis both to misrepresentation, deception, or undue influence and to another grievance are shown in Table IV as stating the grievance other than misrepresentation. In $9 \%$ of the complaints both misrepresentation, deception, or undue influence and another grievance were stated. Thus, a total of $27 \%$ alleged misrepresentation, deception, or undue influence.

The complaints were coded as alleging misrepresentation, 
deception, or undue influence if the complainant's perception of the seller's conduct in such terms could be judged from the complaint. The coding criterion was the complainant's subjective perception of his situation. Although the coding involved subjective judgments on the part of the coders, they attempted to code the complainant's perception of the seller's conduct and not their own. One complaint, for example, stated that the complainant had seen a newspaper advertisement for driveway blacktopping. The ad described the product in glowing terms as "weather resistant, guaranteed not to crack for at least three years." Within months after complainant's driveway was paved, it began to crack. The complainant demanded that the paving company return and repave the driveway with better quality materials. The company refused, saying that the ground was muddy and that paving sometimes cracks under such circumstance. The complainant's letter to the Bureau condemned the seller for using poor material and doing shoddy work, but did not refer to the assurances in the advertisement; therefore, the complaint was coded as not alleging misrepresentation. Other complainants in similar situations complained of the dishonesty of the company in repeatedly assuring them how long the paving would last. The transactions may have been objectively similar, but the buyers perceived, or at least articulated, the problem quite differently. Similarly, in high pressure door-to-door sales cases, some complainants objected to the high pressure tactics and false promises, while others said that they did not have much money and could not afford to pay so much for a product or service of such low quality.

Table $\mathrm{V}$ shows the proportion of various types of transactions underlying Bureau complaints where the buyer alleged misrepresentation, deception, or undue influence. For each type of underlying transaction, column 1 shows the proportion of the dollar value of Bureau complaints of the type alleging misrepresentation, deception, or undue influence; column 2 shows the proportion of the number of Bureau complaints (not weighted for the dollar value of each transaction) so alleging; and column 3 shows the proportion of the total number of Bureau complaints involving the type of transaction. For the whole sample (complaints of all types), $28 \%$ of the dollar value of complaints and $27 \%$ of the number of complaints involved such allegations. 
TABLE $\mathrm{V}$

Proportion of Bureau Complatnts Alleging Misrepresentation ${ }^{40}$

\begin{tabular}{|c|c|c|c|}
\hline $\begin{array}{l}\text { Type of Goods } \\
\text { or Services }\end{array}$ & $\begin{array}{l}\text { Proportion of } \\
\text { Bureau Complaints } \\
\text { Alleging Misrepre- } \\
\text { sentation Weighted } \\
\text { by Size (to } \\
\text { nearest \%) }\end{array}$ & $\begin{array}{l}\text { Proportion of } \\
\text { Bureau Complaints } \\
\text { Alleging Misrepre- } \\
\text { sentation (Un- } \\
\text { weighted) (to } \\
\text { nearest \%) }\end{array}$ & $\begin{array}{l}\text { Proportion } \\
\text { of Bureau } \\
\text { Complaints }\end{array}$ \\
\hline Medical Care & $100 \%$ & $100 \%$ & $1 \%$ \\
\hline $\begin{array}{l}\text { Food, Beverages, Tobacco } \\
\text { and Personal Care }\end{array}$ & 95 & 33 & 3 \\
\hline Books, Magazines, and Records & 93 & 55 & 4 \\
\hline Real Estate & 60 & 41 & 7 \\
\hline Travel & 43 & 17 & 1 \\
\hline Automobiles & 41 & 31 & 22 \\
\hline Recreation & 41 & 19 & 6 \\
\hline $\begin{array}{l}\text { Personal Business and Financial } \\
\text { Planning }\end{array}$ & 33 & 29 & 7 \\
\hline Schools and Self-Improvement & 25 & 38 & 8 \\
\hline $\begin{array}{l}\text { TV, Radio, and Stereo } \\
\text { Household Furniture and }\end{array}$ & 24 & 20 & 5 \\
\hline $\begin{array}{l}\text { Appliances } \\
\text { Apusenord and }\end{array}$ & 18 & 30 & 10 \\
\hline $\begin{array}{l}\text { Home Construction and } \\
\text { Improvement }\end{array}$ & 10 & 5 & 13 \\
\hline $\begin{array}{l}\text { Air Conditioning and Heating } \\
\text { Systems }\end{array}$ & 9 & 27 & 2 \\
\hline Investment and Franchises & 4 & 38 & 4 \\
\hline Clothing, Jewelry, and Furs & 0 & 5 & 4 \\
\hline Banks and Insurance & 0 & 0 & 2 \\
\hline Other & 0 & 0 & 1 \\
\hline $\begin{array}{l}\text { TOTAL (all types of goods } \\
\text { and services) }\end{array}$ & $28 \%$ & $27 \%$ & $\begin{array}{l}100 \% \\
(N=449)\end{array}$ \\
\hline
\end{tabular}

This ranged from medical care complaints, all of which alleged misrepresentation, deception, or undue influence, to complaints involving clothing, jewelry, and furs, banks and insurance, and other transactions, where no such allegations were made. ${ }^{41}$

40 Weighting of Bureau complaints is as explained in note 38 supra.

11 Table V-A sets out the comparison of the distribution of Bureau complaints alleging misrepresentation, deceit, and undue influence with the distribution of national consumer expenditures for various types of goods and services. This comparison is set out in a separate table because the national expenditure data could not be obtained in sufficient detail to allow use of the breakdown of types of goods and services in Table V. Table V-A uses the less detailed categories of types of goods 
The demography of the complainant and size of the dispute were related to whether the complainant explicitly alleged misrepresentation, deception, or undue influence. Such allegations also were significantly associated with the race and sex

and services used in Table II. Column 1 of Table V-A shows the proportion of dollar value of Bureau complaints alleging misrepresentation, deceit, or undue influence involving each type of goods and services. Column I refers only to complaints in the sample which make such allegations $(\mathrm{N}=117)$. Column 2 of Table V-A shows the proportion of dollar value of all Bureau complaints involving each type of goods and services (this is the same data as shown in column 2 of Table II). Column 3 of Table $V-A$ shows the proportion of national consumer expenditures for each type of goods and services (this is the same data as shown in column 3 of Table II). $\bar{A}$ comparison of columns 1 and 3 of Table V-A show's the comparison of complaints alleging misrepresentation, deceit, or undue influence with total national consümer expenditures, both measured by dollar value of transactions by type of goods and services.

TABLE V-A

Comparison of Distribution of Bureau Complaints Alleging Misrepresentation with Distribution of Consumer Expenditures for Types of Goods and Services

\begin{tabular}{|c|c|c|c|}
\hline $\begin{array}{l}\text { Types of Goods } \\
\text { or Services }\end{array}$ & $\begin{array}{l}\text { rtion of Bureau } \\
\text { plaints Alleging } \\
\text { iepresentation } \\
\text { ghted by Size }\end{array}$ & $\begin{array}{l}\text { (To nearest \%) } \\
\text { Proportion of All } \\
\text { Bureau Complaints } \\
\text { Weighted by Size }\end{array}$ & $\begin{array}{l}\text { Proportion of } \\
\text { U.S. Consumer } \\
\text { Expenditures }\end{array}$ \\
\hline Housing & $38 \%$ & $40 \%$ & $15 \%$ \\
\hline Transportation & 37 & 34 & 13 \\
\hline $\begin{array}{l}\text { Personal Business (includes banks, } \\
\text { insurance and credit companies, in- } \\
\text { vestment advisors, franchisors, em- } \\
\text { ployment agencies, etc.) }\end{array}$ & 9 & 13 & 6 \\
\hline $\begin{array}{l}\text { Food, Beverages, Tobacco, and Per- } \\
\text { sonal Care }\end{array}$ & 5 & 2 & 25 \\
\hline $\begin{array}{l}\text { Household (includes furniture, equip- } \\
\text { ment, housewares, appliances, ra- } \\
\text { dio, television, etc.) }\end{array}$ & 3 & 5 & 14 \\
\hline Recreation and Travel & 2 & 2 & 6 \\
\hline Medical Care & 0 & 0 & 8 \\
\hline Clothing, Jewelry, Accessories & 0 & 3 & 10 \\
\hline $\begin{array}{l}\text { Other (includes schools and self-im- } \\
\text { provement, books, magazines, etc.) }\end{array}$ & $\begin{array}{c}4 \\
98 \% \\
N=117)\end{array}$ & $\begin{array}{c}3 \\
102 \% \\
(N=438)\end{array}$ & $\begin{array}{c}4 \\
101 \%\end{array}$ \\
\hline
\end{tabular}

Percentages for U.S. Personal Expenditures are from U.S. Census BurEau, supra note 38 . Bureau complaints weighted as explained in note 38 supra. 
of complainants. Both white ${ }^{42}$ and male ${ }^{43}$ complainants made such allegations more often than black or female complainants. Higher income complainants also seem to have alleged misrepresentation, deception, or undue influence more often, although the association was not statistically significant. ${ }^{44}$ Whether these

12

Race and Allegation of Misrepresentation, Deception OR UNDUE INFLUENCE

\begin{tabular}{lcc}
\hline & White & Complainant Race \\
& Black \\
\hline Alleged misrepresentation, etc. & $31 \%$ & $9 \%$ \\
Did not allege misrepresentation, etc. & 69 & 91 \\
& $100 \%$ & $100 \%$ \\
& $(\mathrm{~N}=252)$ & $(\mathrm{N}=33)$ \\
\hline
\end{tabular}

Chi square test is significant at the .01 level; complaints where race could not be determined are omitted, see note 35 supra.

13

Sex and Allegation of Mispepresentation, Deception OR UNDUE INFLUENCE

\begin{tabular}{lcc}
\hline & \multicolumn{2}{c}{ Complainant Sex } \\
& Male & Female \\
\hline Alleged misrepresentation, etc. & $30 \%$ & $21 \%$ \\
Did not allege misrepresentation, etc. & 70 & 79 \\
& $100 \%$ & $100 \%$ \\
& $(\mathrm{~N}=260)$ & $(\mathrm{N}=180)$
\end{tabular}

Chi square test is significant at the .05 level; complaints where sex could not be determined are omitted.

a

Income Level and Allegation of Misrepresentation, Deception OR UNDUE INFLUENCE

\begin{tabular}{|c|c|c|c|c|c|c|}
\hline & \multicolumn{6}{|c|}{ Complainant Income } \\
\hline & $\stackrel{\$ 0-}{7,999}$ & $\begin{array}{c}\$ 8,000- \\
9,999\end{array}$ & $\begin{array}{c}\$ 10,000- \\
11,999\end{array}$ & $\begin{array}{r}\$ 12,000 \\
13,999\end{array}$ & $\begin{array}{c}\$ 14,000- \\
16,999\end{array}$ & $\begin{array}{c}\text { Over } \\
\$ 17,000\end{array}$ \\
\hline $\begin{array}{l}\text { Alleged misrepresen- } \\
\text { tation, etc. }\end{array}$ & $11 \%$ & $20 \%$ & $25 \%$ & $35 \%$ & $34 \%$ & $32 \%$ \\
\hline $\begin{array}{l}\text { Did not allege mis- } \\
\text { representation, etc. }\end{array}$ & $\begin{array}{c}89 \\
100 \% \\
(\mathrm{~N}=36)\end{array}$ & $\begin{array}{c}80 \\
100 \% \\
(N=35)\end{array}$ & $\begin{array}{c}75 \\
100 \% \\
(N=97)\end{array}$ & $\begin{array}{c}65 \\
100 \% \\
(\mathrm{~N}=91)\end{array}$ & $\begin{array}{c}66 \\
100 \% \\
(N=44)\end{array}$ & $\begin{array}{c}68 \\
100 \% \\
(N=31)\end{array}$ \\
\hline
\end{tabular}

Chi square test is significant at the .07 level, not within the .05 level at which findings are conventionally accepted; complaints where income could not be determined are omitted, see note 32 supra. 
allegations were made was also associated with the stated dollar amount in dispute-the larger the dispute, the more often misrepresentation, deception, or undue influence was alleged. ${ }^{\mathbf{4 5}}$ This association was most clearly illustrated by the numerous complaints against car dealers for selling defective cars which soon needed to be repaired at buyer's expense. Where repairs were expensive, the dealer was often characterized as dishonest and as selling cars he knew were falling apart. Where the repairs were less costly, complainants were less apt to make judgments about the dealer's honesty and more apt to say only how unfair it was that they had to pay anything or to complain that the car did not run properly.

Although the data are not conclusive, these associations suggest the hypothesis that allegations of misrepresentation, deception, or undue influence relate to the characteristics of complainants and the saliency of the disputes to them rather than solely to the objective actions of the businesses involved. There is nothing new in suggesting that different people perceive the same objective events in different ways. The differing perceptions of crumbling pavement illustrate differences in perceptions of identical events. These associations, however, imply that such perceptions are associated systematically with demographic and saliency variables.

It might be that these data are reflecting the relationships suggested by Carlin, Howard, and Messinger ${ }^{46}$ concerning legal competence, adversariness, and assertiveness. According

45

Amount in Dispute and Allegation of Misrepresentation, DECEPTION OR UNDUE INFLUENCE

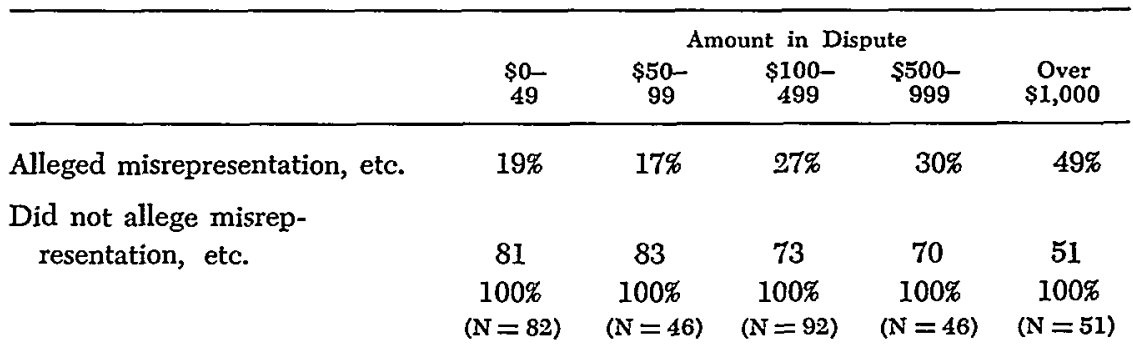

Chi square test is significant at the .01 level; complaints where dispute size could not be determined are omitted.

${ }^{46} \mathrm{~J}$. Carlin, J. Howard \& S. Messinger, supra note 29. See also F. Marks, The Legal Needs of the Poor: A Critical Analysis (1971); Levine \& Preston, supra note 28 . 
to such theories, higher income white males may simply be those with the most "legal competence," those who more easily identify and aggressively assert their rights, and those who perceive more fraud and take a more accusatory stance in relation to their transactions. One might speculate that those with the most experience in dealing with strangers in business transactions are the most adept in separating business affairs from the emotional ways of interacting in primary groups such as family and community, and thus are more able (or more likely) to take a strong and even accusatory stance in such business relationships. Similarly, the association between the amount in dispute and the allegation of misrepresentation, deception, or undue influence suggests that it may be the salience of the dispute for the complainant, not the conduct of the seller, which shapes the complainant's perception of the situation.

\section{E. What the Complainants Wanted}

The overwhelming majority of complainants sought redress of their private grievances. Not surprisingly, they sought the dispute intervention response of the Bureau. Most complainants were highly emotional and were concerned about crisis problems in connection with consumer purchases. Most felt injured and unfairly treated by sellers who failed to complete transactions, delivered defective goods, or performed services inadequately; they sought help from the Bureau in dealing with the present crisis. Typically, the Bureau was asked to take up individual cases against sellers by "making" them give the buyers what they were entitled to. Several complainants said they wanted the Bureau to take the seller to court for them to get their money back. ${ }^{47}$

${ }^{47}$ Several typical complaints read in part as follows:

$X$ came to fix my roof last December. It's March now and my roof still leaks. I need help getting $X$ to finish the job. Two men came out and worked on the roof all day. I paid them $\$ 300$. They left saying they needed some supplies and they'd return and finish up in a few days. I keep calling but all they say is they will come. They never do. Here are pictures of my living room showing how the paint is ruined. I need to have the leak fixed. Please help me get them to finish the job.

I ordered a new car from $Y$ dealer two weeks ago. Now they say that it is ready to be picked up and that I owe them $\$ 3682$. That is $\$ 150$ more than I agreed to pay. I go to pick it up and they tell me they have rust-proofed the car and it costs $\$ 150$. I don't want the car rust-proofed. Now they have my deposit of $\$ 250$ and they won't give me the car for what they agreed to sell it to me for.

$Z$ company wrote me a letter telling me how I could earn $\$ 100$ a week at home by working for just a few hours if I would simply return the coupon with a check for 
Table VI shows the types of remedies requested in the complaints in the sample. Twenty-three percent wanted the transaction performed or completed. Only $14 \%$ wanted the transaction canceled and their money returned. Fifty percent wanted restitution in the form of partial refund, repair, or replacement. More than half of the complainants, therefore, were seeking to have the transactions completed as originally conceived. A relatively small proportion wanted the transaction terminated.

TABLE VI

Priniary Remedies Requested by Complannants ${ }^{48}$

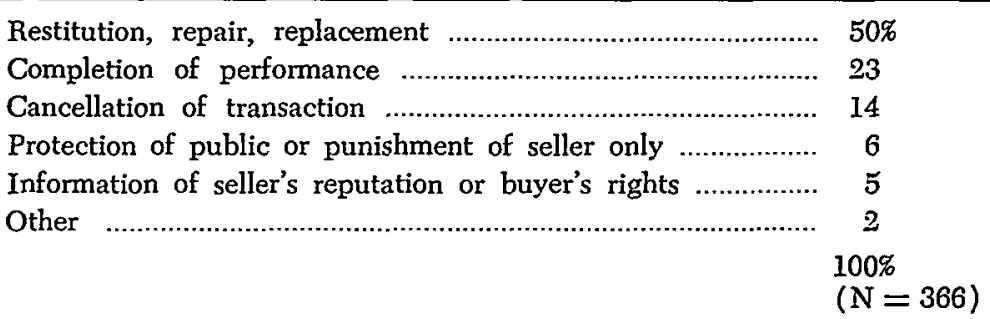

The complainants generally did not seek compensation for their time, expense, or inconvenience. Their concept of equity was typically limited to having the transaction completed, repaired, or terminated. Some commentators have seen the failure to obtain consequential damages as a serious failing of consumer fraud bureaus. ${ }^{49}$ It is interesting to note that the complainants themselves generally do not articulate such demands to the

$\$ 25$ for the supplies and an instruction book and to cover postage. Well I just got the stuff today and all it is is a pile of form letters about ordering encyclopedias and a letter from them saying I will get $\$ 10$ for each person I write to that orders one. I know this isn't worth $\$ 25$ and that I'll never make a hundred dollars a week no matter who I write to. They really cheated me. I don't have much money and I can't spare twenty-five dollars for this junk that is why I want to make some extra money and answered the letter.

I don't know what to do. I went to $W$ store and picked out a sofa. When they delivered it it wasn't the same I had picked out. They say that they didn't have any more of the color I wanted because a salesman didn't know the one I chose was sold and sold it to someone else. Well I don't want the red sofa that I have because my husband likes the gold color much better. But he said that if we can't get the color we wanted then we shouldn't have to pay so much for the sofa which we didn't really want. We're willing to keep the sofa but not for the full $\$ 800$. $W$ already assigned the note to the finance company and the sofa we picked out was the last one they had.

${ }^{48}$ Complaints not specifying any remedy (83) are omitted.

${ }^{49}$ E.g., P. Schrag, Counsel for the Deceived $187-88$ (1972). 
Bureau. Only $14 \%$ of the complaints stated the amount in dispute to be in excess of the amount of the transaction, while $71 \%$ stated the amount in dispute as the amount of the transaction and $15 \%$ stated the amount actually paid.

Rarely do complaints to the Bureau concern chronic social problems in which the complainant has no immediate private stake. Rather, it is an immediate injury and an active dispute that motivates complainants. Only $12 \%$ in all requested publicoriented remedies-for example, that the seller be punished or prevented from continuing his fraudulent business practices or that the public be warned or protected. That $12 \%$ includes both complainants who sought only public-oriented remedies (shown in Table VI) and those who sought both private and public-oriented ones.

Most complainants were seeking remedial action by the seller to complete the transaction; most complaints were framed as conflicts where the primary issue was who was to bear a perceived loss. The dispute concerned the quality of the goods or services themselves. Where the issues of misrepresentation, deception, or undue influence were raised or where a publicoriented remedy was sought, the dispute appears to have shifted away from the complainant's loss and who was to bear it, toward the situation's normative definition and whether the seller had committed an offense.

As with the allegation of misrepresentation, deception, or undue influence, the request for a public remedy is associated with demographic factors and with the size of the dispute. White complainants sought public remedies more often than black complainants, ${ }^{50}$ and higher income complainants more often

50

Race and Request for Public-Oriented Remedx

\begin{tabular}{lcc}
\hline & \multicolumn{2}{c}{ Complainant Race } \\
& White & Black \\
\hline Public remedy requested & $13 \%$ & $0 \%$ \\
No public remedy requested & 87 & 100 \\
& $100 \%$ & $100 \%$ \\
& $(\mathrm{~N}=205)$ & $(\mathrm{N}=24)$ \\
\hline
\end{tabular}

Chi square test is significant at the .13 level, not within the .05 level at which findings are conventionally accepted; complaints where race could not be determined (164), see note 35 supra, and where remedy was not specified (77) are omitted. 
than lower income ones. ${ }^{51}$

One white complainant with an income of over $\$ 15,000$ had signed up for a series of twenty karate classes on the assurance that he could cancel without any obligation after the first class and have his $\$ 400$ fully refunded. After the first class he tried to cancel but was told that he had a contract for the course that could not be broken. His complaint concluded, "It is a crime people like this are allowed to be out of prison cheating everyone. Can't you punish them and make them stop doing this sort of crooked stuff to people."

The association of demographic factors with the demand for public-oriented remedies again seems consistent with the notion of legal competence. ${ }^{52}$ Some people may simply be more sensitive to the infringement of their rights, more "rights conscious," 53 more prone to perceive the conduct of parties with whom they are in conflict in normative terms and to demand that "The Law" be enforced. In other words, one might speculate that the demand for a public remedy is consistent with the tendency to perceive conflict in terms of issues of principle-the moral absolutes of one's legal rights-rather than in terms of the give-and-take of compromising and interpersonal adjustment.

It might be objected that these speculations stray too far from the data in inferring broad conceptual patterns from what may be nothing more than evanescent fits of pique, stubbornness, or the desire to "get the bastards." This characterization of what I have referred to in the complaints as allegations of fraud and demands for public-oriented remedies is not incon-

51

Income Level and Request for Public-Oruented Remedy

\begin{tabular}{lcccc}
\hline & \multicolumn{2}{c}{ Complainant Income } \\
& $\begin{array}{c}\$ 0- \\
11,999\end{array}$ & $\begin{array}{c}\$ 12,000- \\
13,999\end{array}$ & $\begin{array}{c}\$ 14,000- \\
16,999\end{array}$ & $\begin{array}{c}\text { Over } \\
\$ 17,000\end{array}$ \\
\hline Public remedy requested & $4 \%$ & $11 \%$ & $16 \%$ & $28 \%$ \\
No public remedy requested & 96 & 89 & 84 & 72 \\
& $100 \%$ & $100 \%$ & $100 \%$ & $100 \%$ \\
& $(\mathrm{~N}=135)$ & $(\mathrm{N}=75)$ & $(\mathrm{N}=37)$ & $(\mathrm{N}=25)$ \\
\hline
\end{tabular}

Chi square test is significant at the .001 level; complaints where income could not be determined (115), see note 32 supra, and where remedy was not specified (77), are omitted.

${ }^{52}$ See J. Carlin, J. Howard \& S. Messinger, supra note 29.

${ }^{53}$ See Friedman, supra note 29. 
sistent with my admittedly speculative suggestions. The startling fact that the frequency of having and/or articulating such fits of indignation (if that is the proper characterization) is correlated with race and income level indicates that perception of rights, reaction to conflict situations, and use of legal resources vary profoundly among demographic groups. ${ }^{54}$

Requests for public remedies were more common when the amount in dispute was small. ${ }^{55}$ The negative correlation between dispute size and demand for public remedy seems explicable in terms of the motivations of complainants to complain. One's motivation to seek a private remedy quite reasonably varies positively with the amount in dispute-the saliency of the dispute to him. Where the amount is small, saliency would be low, and fewer complainants would be motivated to seek only a private remedy; if they were to complain at all, it would likely be for public-oriented relief. The most extreme example was a complaint about a fast-food chain for overcharging on the state sales tax: "While I have lost only one cent they are cheating the public out of millions of dollars by overcharging everyone this way. This is a gross fraud and must not be allowed to go on."

Four percent of the complainants in the sample requested only information. Over half of these ( $2 \%$ of the total sample)

${ }^{4}$ S. Ranulf, Moral, Indignation and Middle Class Psychology (1964), presents a historical analysis of the conditions under which a well-developed system of criminal law appears in society and concludes that "the disinterested tendency to inflict punishment is a distinctive characteristic of the lower middle class . . . Id. 198. In the present context one might speak of the tendency to define consumer disputes in absolute normative terms and to demand public responses, and suggest that it is a middle class phenomenon.

se

Amount in Dispute and Request for Public-Oriented Remedy

\begin{tabular}{lcccccc}
\hline & $\begin{array}{c}\$ 0- \\
9\end{array}$ & $\begin{array}{c}\$ 10- \\
49\end{array}$ & $\begin{array}{c}\text { Amount in dispute } \\
\$ 50-\end{array}$ & $\begin{array}{c}\$ 100- \\
499\end{array}$ & $\begin{array}{c}\$ 500- \\
999\end{array}$ & $\begin{array}{c}\text { Over } \\
\$ 1,000\end{array}$ \\
\hline $\begin{array}{l}\text { Public remedy } \\
\text { requested }\end{array}$ & $23 \%$ & $16 \%$ & $10 \%$ & $4 \%$ & $5 \%$ & $10 \%$ \\
$\begin{array}{l}\text { No public remedy } \\
\text { requested }\end{array}$ & 76 & 84 & 90 & 96 & 95 & 90 \\
& $\begin{array}{c}100 \% \\
(\mathrm{~N}=30)\end{array}$ & $\begin{array}{c}100 \% \\
(\mathrm{~N}=45)\end{array}$ & $\begin{array}{c}100 \% \\
(\mathrm{~N}=40)\end{array}$ & $\begin{array}{c}100 \% \\
(\mathrm{~N}=82)\end{array}$ & $\begin{array}{c}100 \% \\
(\mathrm{~N}=39)\end{array}$ & $\begin{array}{c}100 \% \\
(\mathrm{~N}=41)\end{array}$ \\
\hline
\end{tabular}

Chi square test is significant at the .05 level; complaints where dispute size could not be determined (121) and where remedy was not specified (77) are omitted. 
sought advice on their rights in a present disputed transaction, the remainder $(2 \%)$ sought information about a business before entering into a transaction with it. Although one of the main themes of consumer education is that one should seek information about the seller before buying, the Bureau generally declined to give such information. None of the complaints in the sample that sought information was acted upon, though hearing officers said informal advice was occasionally given about where the complainant might go for help.

\section{F. What Complainants Did Before Complaining to the Bureau}

Many complaints to the Bureau involve transactions started long before the complaint. Some transactions, especially those involving construction or major installations, inherently take substantial amounts of time to perform. Others may be protracted for such reasons as the need for an appointment to get into a house or for successive attempts to repair a car. This section explores what people do to cope with disputes over what period of time. Table VII shows the timespan between the date the dispute arose and the date of the complaint to the Bureau. In some cases the date the dispute arose is difficult to determine. For example, how long does one wait for a building contractor to return to finish a job? How many excuses does the buyer believe, and at what point does he perceive the excuses as unreasonable? A certain length of time is necessary to have defects corrected, and this delays the definition of the situation as a dispute. Realizing that much subjective judgment was involved, the coders estimated when that condition occurred.

TABLE VII

Span of Time from Dispute to Compraint ${ }^{\text {G }}$

\begin{tabular}{lc}
\hline 1 day & $2 \%$ \\
$2-7$ days & 12 \\
$8-30$ days & 24 \\
31-90 days & 26 \\
$91-180$ days & 16 \\
over 180 days & 20 \\
& $100 \%(\mathrm{~N}=298)$ \\
\hline
\end{tabular}

${ }^{56}$ Cases where timespan could not be determined (151) are omitted. 
Many disputes are relatively old when they are brought to the Bureau. The variance in the length of time and the actions taken during that time may reveal differing styles of coping with disputes. One way to approach the question is to ask to what extent the differences in the ages of the disputes are accounted for by bargaining between the parties and by the use of other third party resources, and to what extent they reflect the characteristics of different complainants. We know from the interviews that lack of knowledge of available resources for help caused much of the delay. ${ }^{57}$

We would expect the initial response of a buyer in coping with a dispute to be to contact the seller to attempt direct resolution. Caplovitz found that half of the low income consumers he interviewed did nothing at all, and another $40 \%$ complained to the merchant. He found that only $9 \%$ sought "professional" help, which would include complaining to the Bureau or other community resources. ${ }^{58}$ After the dispute arose but before contacting the Bureau, $72 \%$ of the complainants contacted the seller, $9 \%$ tried unsuccessfully to contact him, and $19 \%$ did not attempt to make contact. The stereotypical case of fraud in which the seller disappears after taking the buyer's money is not prevalent among complaints received by the Bureau.

The length of time from dispute to complaint was accounted for in part by contact between the parties. Complaints to the Bureau were made most promptly when no attempt to contact the seller had been made, and the delay was greatest when the complainant had attempted to contact the seller and awaited his response. Table VIII shows the relationship between attempted contact and delay to complain.

Where there was bargaining activity prior to complaint to try to settle the dispute, longer delays in complaining occurred. As long as the bargaining process had not yet broken down, the complainant apparently saw less need for a third-party resource. Bargaining was coded on the basis of the complainant's report in the complaint that the seller had bargained, or offered some compromise or partial relief, before complaint to the Bureau.

Table IX shows the relationship between prior bargaining and delay in complaining. Almost half (48\%) of the complain-

57 D. Caplovitz, supra note 27 , at 175 , reports finding that $64 \%$ of his sample did not know of resources for help with a consumer dispute.

58 Id. 171. 
TABLE VIII

Buyer Attentpt to Contact Seller and Time from Dispute to Bureau CoMplaint ${ }^{50}$

\begin{tabular}{lccc}
\hline $\begin{array}{c}\text { Time from Dispute } \\
\text { to Bureau } \\
\text { Complaint }\end{array}$ & $\begin{array}{c}\text { none } \\
\text { attempted }\end{array}$ & $\begin{array}{c}\text { Contact Between Parties } \\
\text { unsuccessful } \\
\text { attempt }\end{array}$ & contact \\
\hline Under I month & $64 \%$ & $26 \%$ & $42 \%$ \\
I-3 months & 15 & 33 & 24 \\
$3-6$ months & 10 & 26 & 14 \\
Over 6 months & 11 & 15 & 20 \\
& $100 \%$ & $100 \%$ & $100 \%$ \\
& $(\mathrm{~N}=61)$ & $(\mathrm{N}=27)$ & $(\mathrm{N}=245)$ \\
\hline
\end{tabular}

ants had taken their disputes to other community resources before coming to the Bureau, $9 \%$ had taken their disputes to two other resources, and $4 \%$ to more than two. Table $\mathrm{X}$ shows

TABLE IX

Bargaining Between Parties and Tine from Dispute to Bureau Complainto

\begin{tabular}{lcc}
\hline $\begin{array}{c}\text { Time from Dispute } \\
\text { to Bureau } \\
\text { Complaint }\end{array}$ & Bargaining & $\begin{array}{c}\text { Contact but no } \\
\text { Bargaining } \\
\text { (to nearest \%) }\end{array}$ \\
\hline Under I month & $36 \%$ & $46 \%$ \\
1-3 months & 19 & 26 \\
3-6 months & 17 & 13 \\
Over 6 months & 28 & 16 \\
& $100 \%(\mathrm{~N}=78)$ & $101 \%(\mathrm{~N}=167)$ \\
\hline
\end{tabular}

the distribution of prior resources used by complainants. Many informal, but few formal, resources were used; only two complainants had filed lawsuits before complaining to the Bureau.

Complainants who contacted other resources before complaining to the Bureau delayed longer in contacting the $\mathrm{Bu}$ reau than those who did not. The more prior resources the complainant had contacted, the longer was the delay. The longest delays were in cases where the prior resource had actively

59 Chi square test significant at .01 level. Complaints where time to complaint could not be determined (116) are omitted.

${ }^{60}$ Chi square test is significant at .06 level, not within the .05 level at which findings are conventionally accepted. Complaints where time to complaint could not be determined (116) and where there was no contact between the parties prior to Bureau complaint (132) are omitted. 
TABLE $X$

Resources Contacted Before Bureau Complaint ${ }^{01}$

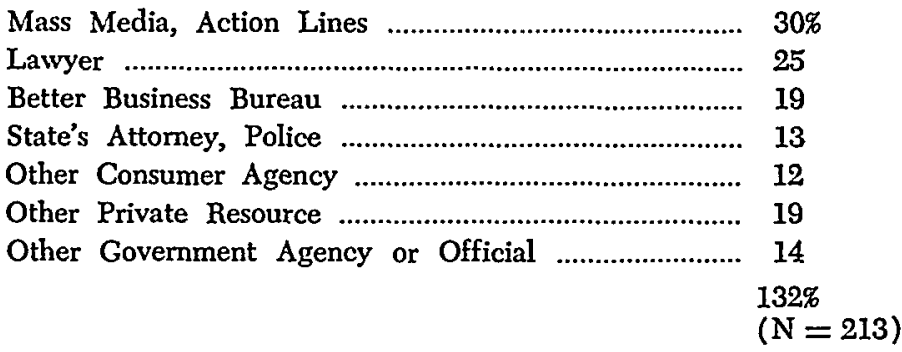

intervened rather than simply advising the complainant, or doing nothing. Better Business Bureaus and mass media action lines actively intervened relatively often, and delayed complaint to the Bureau in the cases taken to them. Lawyers, where used, played a more passive role-advising and referring; they actively intervened in very few cases later complained about to the Bureau. Lawyers and the media were the most frequent sources of referrals to the Bureau, each referring about $8 \%$ of the total sample.

It is interesting to note that virtually none of the complainants had taken his grievance to a court before coming to the Bureau. Complainants who had consulted lawyers sought either advice or informal intervention, but not the filing of lawsuits. The range of institutions that the complainants had contacted prior to coming to the Bureau reveals some information about the hierarchy of dispute management institutions previously discussed. ${ }^{62}$ Bureau complainants frequently had attempted to solve their disputes by themselves by direct negotiation with the seller. They often then sought the intervention of one or more informal community resources. All of these resources and the Bureau are located on the informal portion of the continuum described in Figure I. As we shall see, if the Bureau is unsuccessful in its intervention, it often refers complainants to the courts. Consumers thus appear to seek the intervention of a sequence of institutions of increasing formality and resource requirements in dealing with their disputes.

61 The total represents 289 resources used by 213 complainants, hence the total percentage is greater than $100 \%$. Complainants contacting no resources other than the Bureau (236) are omitted.

${ }^{62}$ See Figure I \& part I supra. 


\section{The Bureau's Response to Complaints}

The nature of the Bureau's response to the complaints can best be understood by following the typical course of a complaint. More than half of the complaints are received by mail, either on complaint forms supplied by the Bureau or in informal letters. The balance of complaints is filed in person at the $\mathrm{Bu}$ reau's office. As soon as the Bureau receives a complaint, a file is opened and the case is assigned to a hearing officer. Most of the hearing officers are lawyers. On the basis of the complaint alone the hearing officer decides whether or not to contact the seller to ask for its response to the complaint. When he receives the seller's response, the hearing officer again reviews the file and may either close the matter or set an informal hearing to discuss the dispute. After the hearing, the matter usually is either settled between the parties or dropped by the Bureau. Occasionally, complaints are referred to Bureau lawyers for further investigation, and, perhaps, for litigation. The average length of processing time from receipt of a complaint to disposition is 2.6 months for all cases, and 3.6 months for those where the seller is contacted.

Files are closed at three primary disposition points in the complaint-handling process: (1) when the complaint is received; (2) when the seller's answer is received; and (3) at the informal hearing. At each disposition point there are various types of dispositions: The Bureau may decide that it has no jurisdiction over the particular seller or the type of business, or that no good claim has been alleged; the complainant may drop out of the case by failing to respond further; the Bureau may be unable to contact the seller; the dispute may be settled; or the matter may be sent on to be investigated for possible law enforcement activity, and thus depart from the routine complaint-handling process. Figure IV shows the proportion of the complaints in the sample disposed of at each disposition point and the type of disposition. Each stage of the process will be discussed in somewhat more detail.

\section{A. After Receipt of the Complaint: \\ The Decision to Take Action}

Some preliminary screening takes place through verbal discouragement or referral by the receptionists and telephone operators, and by attrition through the sending of complaint 


\section{FigURE IV}

\section{BuREAu Disposition of Complaints}

Disposition

Points in

Flow Chart of Complaint Dispositions

Bureau Process (percentage of all complaints received is indicated)

Complaints Received by Bureau (100\%)

1. Initial screening of complaints

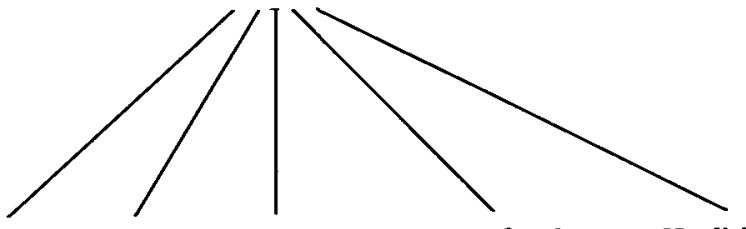

No jurisdic- No claim Bureau No further To litigation tion $(20 \%) \quad(13 \%)$ attempt to complainant department contact seller response $(2 \%)$ $(62 \%)$

$(3 \%)$

2. Screening after seller answers
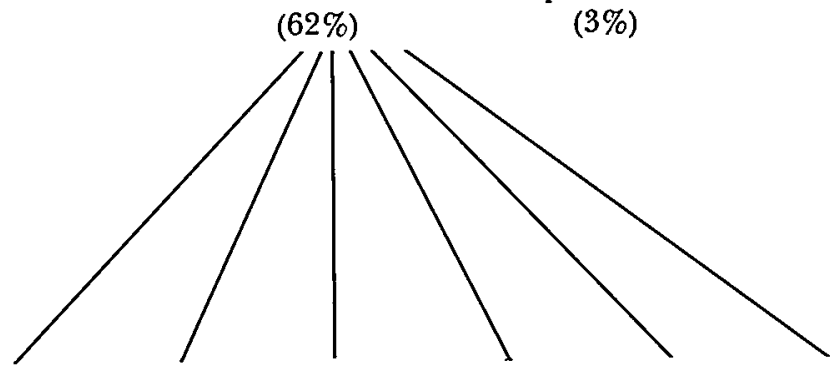

Dispute No claim Hearing No further Cannot To litigasettled (4\%) (18\%) complain- contact tion dept. $(23 \%)$

3. Informal hearing

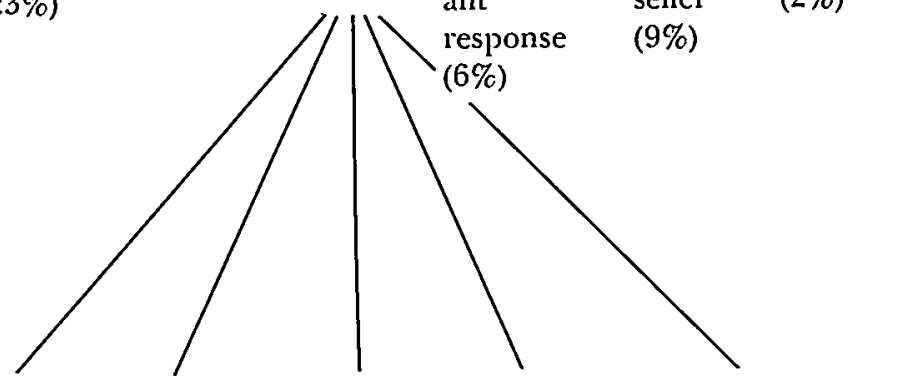

Dispute No claim No further Cannot To litigation dept. settled (4\%) complainant contact (less than 1/2 of 1\%) $(12 \%)$ response (1\%) sellè (1\%) 
forms that are never returned. The analysis which follows is based on the complaints received in writing after such attrition. The Bureau's hearing officers make the major screening decision-the first real disposition point in the process-on the basis of the written complaints.

Over one-third (38\%) of the complaint files are closed at the initial screening stage. The hearing officers base initial screening decisions on their reading of the complaint and on whatever impressions about the reputation and past conduct of the seller they carry in their heads. They make no investigation of the business or other consumers, nor do they check Bureau or other files about past complaints or investigations. Although the ubiquitous problems of understaffing, inaccessibility of information, and lack of staff aggressiveness partially explain the failure to use other sources of information at this and later stages, these are not the primary explanations. Put simply, this decision is not based on the business practices of the seller. This screening is not made from a law enforcement stance, where the criterion for decision would be the normative quality of the seller's past conduct; rather, the screening is done primarily from a dispute settlement perspective-the basis of decision is the legitimacy of the complainant's problem and whether the Bureau can help to solve it.

The majority of complaints screened out at this stage are dropped for lack of jurisdiction, which includes: Seller not in the state $(5 \%)$, seller regulated by other state agency $(8 \%)$, complaint not involving consumer transaction (4\%), and other reasons $(3 \%)$. Such jurisdictional criteria are used quite freely in disposing of complaints. The factors involved are objective and do not require contradicting the complainant. In addition, declining jurisdiction because the seller is out of state or separately regulated allows the Bureau to refer the complainant to another specified resource for help, for example, the consumer agency of another state or a regulatory agency in the state. This encourages use of lack of jurisdiction as a basis for disposition. It is a ready solution to the usual bureaucratic problem of keeping up with the caseload; it closes cases quickly and efficiently. A total of $20 \%$ of the complaints received were screened out for lack of jurisdiction, and $80 \%$ of these complainants were referred by letter to other government agencies. The Bureau did not follow up on such referrals. Referrals were much less frequent if the Bureau took jurisdiction and screened the com- 
plaints out for substantive reasons. Only about $40 \%$ of the cases over which the Bureau took jurisdiction and dismissed at this first disposition point were referred, and referral usually took the form of advice to see a lawyer or, in a few cases, to use the pro se small claims court.

Despite the ease of dropping cases for lack of jurisdiction, the Bureau does on occasion intervene to help a deserving consumer even while deciding that it has no jurisdiction. This happens most often if the hearing officer thinks a letter might easily solve the problem, for example, an out-of-state department store order which appears to be a random error or billing error. ${ }^{63}$

Most of the remaining cases (13\%) screened out at the first disposition point are closed for substantive reasons-no good claim is stated in the complaint. ${ }^{64}$ The decision to close the file on this basis is communicated to the complainant as a finding that the Bureau has determined that there is no allegation of conduct in violation of the consumer fraud statutes. ${ }^{65}$

The hearing officers say that only about $5 \%$ of all complaints received involve situations appearing to violate the statutes, and that these stand out clearly. The officers invariably characterize most complaints as arising out of misunderstandings, inevitable or negligent foul-ups, or breaches of contract which reasonable people should be able to work out. They describe the complainants not as victimized, but as not knowing how to handle their problems or as being a bit unreasonable about their rights. The hearing officers thus seem to perceive and screen the complaints almost entirely from a dispute settlement stance. The decision is based on the hearing officer's judgment

${ }^{63}$ Such cases constituted under $2 \%$ of the sample and are included in "no jurisdiction" on Figure IV.

64 A few complaints drop out at this point because of the failure of the complainant to answer the Bureau's request for additional information (3\%). Some are assigned directly to the litigation department not on the basis of the content of the complaint, but because the business complained about is already independently the subject of litigation department concern (2\%).

65 The Bureau describes this screening process as review to determine:

whether or not the [Bureau] has jurisdiction over the matter under any of the applicable statutes. If the complaint does not relate to applicable statutory sanctions or prohibited methods, or if the complainant is not a "consumer" within the meaning of the Consumer Fraud Act, the file is marked "no jurisdiction" and a letter is forwarded to the complainant informing him of our determination and the reasons therefor. We also suggest contacting a private attorney where we feel the complainant has a possible civil remedy.

[1969-1970] Ill. Atty Gen. Consumer Fraud \& Protection Div. Biennium REP. 3 [hereinafter cited as [1969-70] BrenNiUm REP.]. 
of the credibility of the complainant, the legitimacy of his problem, his entitlement to assistance, and the likelihood that $\mathrm{Bu}$ reau intervention would be helpful. It is the strength of the complainant's request for help, not the appropriateness of the seller as a subject for possible prosecution (law enforcement), that governs this decision. I shall refer to this implicit criterion for screening complaints as the standard of complaint strength.

When the hearing officer decides to act upon a complaint, he has decided both that a legitimate grievance is stated by the complaint (the standard of complaint strength) and that $\mathrm{Bu}$ reau action may help to settle the dispute. ${ }^{66}$ No judgment whether the seller has violated the fraud statutes is made at this stage because it is not relevant to the action of the hearing department. That judgment is suspended pending the processing of the complaint.

The second implicit screening criterion is what I shall call the standard of dispute solvability. If it appears that the action of the Bureau will help the complainant to settle the dispute without too much effort, the Bureau will intervene even if the complaint is not serious and does not involve a high probability of fraud; the standard of solvability leads the Bureau to act on some cases where the complaint is not strong and not to act where strong complaints appear difficult to resolve. Solvability of disputes as a screening standard is illustrated by the hearing officers' occasional intervention in a dispute simultaneous with their decline of jurisdiction. The hearing officers also indicate that there is a lower frequency of Bureau intervention in cases involving defective services or merchandise, which are inherently more difficult to resolve than cases of nondelivery, incomplete performance, or credit or billing problems. They also say that the Bureau intervenes more frequently when the complaint is against a large business than a small one because large businesses are more responsive and will settle disputes more often, and because such complaints are more often the results of unintended errors. Hearing officers indicate that they are more likely to intervene in a case where the complainant has stated the dispute in terms of possible private remedies rather than in terms of punishment of the seller. Complaints that state the complainants' outrage but do not suggest an acceptable outcome indicate to the hearing officers that they will not be resolved easily and

${ }^{66}$ The opposite conclusion is reached in the complaints screened out as "no claim." No conclusion is reached on these issues in those cases dropped for lack of jurisdiction. 
TABLE XI

Buneau Intervention and Type of Remedy Requested ${ }^{67}$

\begin{tabular}{lcccc}
\hline & Cancellation & Rerformance & Restitution & $\begin{array}{c}\text { Other and } \\
\text { unspecified }\end{array}$ \\
\hline Bureau Intervention & $93 \%$ & $86 \%$ & $79 \%$ & $76 \%$ \\
No Bureau Intervention & 7 & 14 & 21 & 24 \\
& $100 \%$ & $100 \%$ & $100 \%$ & $100 \%$ \\
& $(\mathrm{~N}=159)$ & $(\mathrm{N}=72)$ & $(\mathrm{N}=42)$ & $(\mathrm{N}=97)$ \\
\hline
\end{tabular}

that the Bureau might better use its energies elsewhere if it wishes to resolve the maximum number of disputes.

The solvability standard is illustrated further by the Bureau's more frequent action on complaints that sought either completion of performance or cancellation of the transaction rather than restitution or repair, as Table XI demonstrates. Performance or cancellation are clearly defined remedies, often involving situations in which the seller has not performed at all, and probably are easier to resolve than if no remedy is specified or general restitution is requested. Complaints seeking completion of performance generally did not accuse the seller of fraud or misrepresentation, and depicted the seller as unreasonable rather than dishonest; such disputes present fewer problems of resolution. Complaints seeking cancellation generally were made at a point in the transaction before any performance, and thus were more easily resolved both because a clear remedy was indicated and because sellers had made less investment in the transaction.

The use of the standard of solvability is consistent with the Bureau's dispute settlement stance. The Bureau stands ready to intervene and to help to settle private consumer disputes. The Bureau initially perceives complaints as disputes to be settled rather than as alleged fraud to be investigated for prosecution, though the latter more clearly describes the statutory mandate. ${ }^{68}$ One complaint, for example, came from an employee of a building management concern who charged that his employer was cheating the public by misrepresenting its janitorial service. Such a complaint would seem to be important because it is a new and vital source of information about conduct violative of the acts that the Bureau was set up to police. In fact, the $\mathrm{Bu}$ -

${ }^{67}$ Cases where jurisdiction was declined for formal rather than substantive reasons (79) are omitted.

${ }^{68}$ See text accompanying notes $20-23$ supra; note 69 infra. 
reau's structure is not conducive to response to such a routine complaint from a complainant with no stake in the dispute. This complaint was dismissed without action on the ground that the complainant was an employee, and not a consumer within the meaning of the Consumer Fraud Act. The Act, however, does not limit the Bureau's jurisdiction to complaints from parties with a stake in an active dispute. ${ }^{69}$ The complaint file implies that this particular case was closed because the complaint did not present an active dispute in which the complainant had a stake or a significant problem to be solved. The hearing officer apparently saw no occasion for Bureau action.

The Bureau has, in effect, adopted a "case or controversy" or "standing" criterion similar to that of the courts. By acting when the complainant's grievance is strong and the Bureau can easily solve the problem, the Bureau defines itself as a disputesettling institution and a helping resource for aggrieved buyers. Complaints not arising out of an active dispute between a buyer and a seller with a request for a private remedy simply are not congruent with the Bureau's primary dispute settlement stance.

\section{B. Bureau Action on Complaints}

Sixty-two percent of the complaints survive the initial screening stage and are acted upon by the Bureau. First, the Bureau writes a letter to the business complained about, describing the nature of the complaint and inviting a response. The letter neither requests any defense to the allegation of fraud nor seeks evidence of the general business practices of the seller. It presents only the single complaint, and is ambiguous as to whether

${ }^{69}$ The attorney general is empowered to investigate and seek court orders:

[1] When it appears to the Attorney General that a person has engaged in, is engaging in, or is about to engage in any practice declared to be unlawful by this Act; [2] when he receives a written complaint from a consumer or borrower of the commission of a practice declared to be unlawful under this Act; or [3] when he believes it to be in the public interest that an investigation should be made to ascertain whether a person in fact has engaged in, is engaging in or is about to engage in, any practice declared to be unlawful by this Act ....

Ilt. ANs. STAt. ch. 1211/2, § 263 (Smith-Hurd Supp. 1974). Consumer complaint [2] is only one of three bases on which the Bureau may act. The Act does not require that the "consumer or borrower" making the complaint be a party to a transaction with the seller or lender, have a monetary interest in the dispute, or have a special source of knowledge. Rather than any such notions of privity, interest, or special information, the Act apparently contemplates that the Bureau will act on information from any source whatsoever which causes it to "appear" to the Bureau (cl. [1] in quoted portion of $\mathrm{Act}$ ) or causes the Bureau to "believe" (cl. [3]) that an investigation ought to be made. 
it is an accusation of fraud (requiring a defense) or a request for a private remedy.

The form letter sent to the business complained against exhibits the equivocal relationship between the Bureau's formal statutory purpose as a law enforcement agency and its adopted, informal, dispute-settling function. The letter is the Bureau's intervention as a third party for the primary purpose of affecting the outcome of a two-party dispute. The form letter states:

On , 19 , the above-named consumer filed a complaint with this office alleging that you violated one or more of the Illinois consumer fraud and protection statutes.

The following is a brief summary of the allegations against you.

You have the right to respond to these allegations. Your response must be sent within five days of your receipt of this letter. If your response does not demonstrate clearly that there is no substantial claim, the matter will be set for hearing in the near future.

It is our sincere hope that this matter may be resolved without delay.

Very truly yours,

Although the letter speaks of allegations of violation of the consumer fraud statutes, it also speaks of a response which would "demonstrate that there is no substantial claim," and states the hope that the matter may be resolved without delay. What sort of a response could clearly negate an allegation of fraud? It takes only a little reading between the lines to conclude that the matter will be considered closed if the "claim" is remedied or a satisfactory answer to it is given. The law enforcement stance and the dispute settlement stance are mixed in the letter. This implication is strengthened by the complaint summary inserted in the form letter. It is normally described from the point of view of the complainant stating his particular problem. In many cases, the hearing officer goes on to state specifically what he thinks the seller ought to do to take care of the problem. Seldom does the hearing officer simply say that the violation of a certain statute has been alleged, without going on to suggest an acceptable resolution.

The hearing officer assumes a dual role. On the one hand he plays the role of advocate for the complainant, on the other, the role of mediator. Neither role is related to law enforcement. 
Both are related to the solution of the concrete dispute rather than to the application of legal norms that would be involved in the more formal function of law enforcement. When he decides to write the letter, the hearing officer considers what might be an equitable settlement. He considers the seller's probable interests as well as the complainant's stated interests.

The Bureau does not discuss with the complainant what remedy would be satisfactory to him. Unless the complainant requests a specific remedy, the Bureau must decide what resolution is possible and equitable. Even where a specific remedy is requested, the Bureau may seek a different one. The specific settlements which the hearing officers suggested were generally less favorable to complainants than the specific demands. Although the hearing officer takes the side of the complainant in presenting the dispute to the seller, he tempers the demand by his own notions of fairness. He normally does not suggest compensation for delays or loss of use or income. Suggestions of refunds generally allow the seller some allowance for work already performed, most frequently in cases where a partially performed contract is to be canceled. Often, the suggested remedy is an outright compromise. When complainants seek refunds or terminations of relationships, the Bureau commonly converts these into requests for repair, replacement, or completion of performance. The Bureau tends to request completion of performance rather than cancellation, and repair rather than refund. Such transformations of the buyer's demands are, in effect, compromises, because the seller will lose less by retaining some of its profit from the transaction. Such transformations seem to reflect both notions of equity and judgments of what can be obtained without undue effort. The hearing officer's judgment of a fair outcome, not the complainant's, governs the Bureau's demands to sellers. Complainants do not, in fact, know what the Bureau has written to sellers and might not approve if they did.

Some examples will illustrate this transformation, the mixture of advocacy and mediation, and the problem-solving nature of the intervention. One complainant's statement read:

I want my money back. That swindler sold me a TV he knew was full of broken down old parts that would never work. It must have been dropped on the ground or second hand or something. I'll never go near him again. 
This was communicated to the seller as follows:

It is alleged that you sold a television set to the above party that was not in proper repair. We suggest that you repair or replace it promptly.

Another complainant wrote:

$X$ came to repair my plumbing. He did such a lousy job and made such a mess of my house that I had to hire another plumber and a painter to put it back together again. I paid $X \$ 150$ only to have everything ruined for weeks. Then I had to shell out $\$ 325$ more to correct what he did.

The hearing officer stated this complaint to the seller in this way:

$Q$ states that the plumbing repair work you performed for him was defective and that further work was required to correct it. It seems to us that some adjustment of the price would be appropriate under the circumstances.

A third complainant had sent away for a.kitchen gadget from a small and distant mail order house. The Bureau wrote simply "Ship the merchandise ordered or refund the money at once."

The Bureau does not merely ask the seller for his side of the dispute; rather, the Bureau approaches the seller as an advocate for the complainant's legitimate demands as redefined by the hearing officer.

The complaint letter itself is rarely forwarded to the seller. Although having hearing officers summarize complaints generates more work for the Bureau, it serves several important functions. First, it clarifies the complaint. The hearing officer must glean the central issue from an often rambling and unfocused complaint that makes many accusations and demands. He must ascertain the crux of the complaint, determine an equitable settlement, and then state this information in a short paragraph. The concise restatement of the complaint serves to narrow the issues, to strip them of their hostile emotional content, and to state the problem as a request for the seller to remedy a specific problem. The hearing officer may well be able to isolate the problem and define an achievable solution better than the complainant. In addition, the restatement by an assistant attorney general who is both an objective third party and an expert seems greatly to increase the legitimacy of the complaint in the eyes of the business receiving the letter. 
One can only speculate whether the business responds primarily to the clarification and objectification of the complaint or to the implicit threat of law enforcement action. The official restatement of the complaint is a means of communicating the complaint's new status to the seller. Often the seller has ignored the buyer before Bureau action; often the buyer is dissatisfied with the action taken by the seller in response to his complaint. Once the Bureau indicates its interest, and, implicitly, its agreement with the complainant that further seller action would be appropriate, the complaint receives a new legitimacy and a new status-the state has taken official notice of it. The seller sees the complaint as a priority matter and he reviews it again, this time with a predisposition to see merit in the complainant's position now that the state has intervened and joined the complainant.

\section{After the Business Responds: The Second Disposition Point}

At this point in the process, the second major disposition point is reached. ${ }^{70}$ The Bureau now has the complaint and the seller's response to the Bureau's statement, and must decide whether to take further action. If the case is not closed, the next step normally is to set an informal hearing on the complaint, but on occasion the Bureau sends additional letters and makes additional telephone calls to the seller. The criteria of decision at this point are closely related to the standards of complaint strength and solvability implicitly used at the first disposition point.

Some sellers could not be contacted by the Bureau. The hearing officer typically made little effort to locate the seller, although in a few cases an investigator was sent to the address given. When the Bureau's letter was returned as undeliverable or when the Bureau knew from other sources that the seller

70 Assuming that the respondent informs [the Bureau] of facts which clearly negate any fraud and that [the Bureau] is satisfied that such response is a true and accurate description of the transaction complained of, then the file is closed and marked, "no jurisdiction-investigation" (NJI), and the complainant is so informed with our reasons for not accepting the file accompanying the refusal letter.

Typically, arrangements are often made between the parties at this stage with the [Bureau] playing a mediator role. Voluntary settlements negotiated by the parties are discovered by the [Bureau] through a system of "status" letters to both the complainant and the respondent. Settlements are recorded on the file and statistics entered.

[1969-1970] BIENNIUM REP., supra note 65, at 3-4. 
could not be reached (together, $7 \%$ of the complaints), the normal course was to send a letter to the complainant saying that the Bureau was unable to locate the seller and that unless the complainant could supply a better address, no further action could be taken. Unless the complainant sent a new address-a rare occurrence-the case was closed.

Seventy-three percent of the businesses contacted by the Bureau responded to the initial letter, almost all within the five days specified in the form letter. Of those cases in which the businesses did not respond, $70 \%$ ( $15 \%$ of the total sample) were set for hearings, $15 \%$ ( $2 \%$ of the total sample) were dismissed when the complainant failed to respond to the Bureau's further inquiry as to the status of the matter, ${ }^{71}$ and $15 \%$ (2\% of the total sample in addition to the $7 \%$ where the Bureau knew the seller had not been contacted) were dismissed on the basis that the business could not be contacted.

The first criterion used at this disposition point is the equity of the solution offered by the seller. This judgment depends both upon the remedy the seller has offered, if any, and upon a reassessment of the strength of the complaint in light of seller's answer. Cases are invariably closed at this point if the seller indicates that it has given a complete remedy. When a seller indicates that it has taken or will take some action, the Bureau takes its word for it without any follow-up, leaving it to the complainant to inform the Bureau if the proffered action is not taken. The problems of leaving follow-up to complainant prodding will be discussed when the outcomes of the Bureau action are examined.

Thirty-seven percent of the cases where the seller responded (23\% of the total sample) were closed on the basis of the seller's offer to settle the dispute by doing part or all of what the buyer requested. Four percent of the cases were closed with the formal finding that no fraud had occurred, based in most cases on the

71 The form letter to the complainant inquiring about the status of the matter entirely adopts a dispute settling stance. It reads as follows:

Please be advised that this of fice is still reviewing the above complaint. We would appreciate hearing from you as to what disposition might have been made in this matter between you and the above named respondent since this office has last been in contact with you. Upon receipt of the information, this office will contact you as to whether the matter in question warrants action under "An Act to Prevent Consumer Fraud."

If the matter has been settled, we would appreciate notification of the same. If not, please contact us as to the present status of the controversy.

Unless we hear from you within the next ten days by mail, we will assume that you do not want to pursue this matter further. 
hearing officer's decision after reading the seller's answer that the complainant was not entitled to relief.

The dispute solvability standard is also used at this second disposition point. The hearing officer judges whether or not further Bureau action is likely to result in an outcome significantly more favorable to the complainant. Where, for example, a seller's answer disputes the facts of the complaint and offers nothing, hearing officers appear more likely to close the case than where the seller generally agrees about what had happened but takes issue with its liability or its fraud, or alleges mitigating circumstances. The apparent reason for this is the hearing officers' opinion that disagreements over facts are intractable and difficult to settle. Where the issues are drawn as disagreements about the facts, they are apparently less susceptible to bargaining and compromise and thus to mediation than where the issues concern liability on agreed facts. The Bureau, then, applies what we have called the solvability standard to conserve its hearing resources by using them mainly in those disputes where it seems most likely to be able to obtain additional relief for the complainant.

The second disposition point in the complaint handling process of the Bureau is governed by the same two related but separate criteria which govern the first disposition point. The main determinant of disposition is whether the seller has offered a remedy to the complaint that solves the problem. Cases are closed if the seller promises a full solution-the solution requested by the complainant and/or the hearing officer. If less than a full solution or none at all is offered, the Bureau applies its dual criteria of complaint strength and solvability. The strength of the complaint, its size, and the appearance of misrepresentation impel the Bureau to carry the case on to a hearing. The apparent solvability of the dispute-the request for a specific private remedy, the indication of willingness to bargain, the perception of the dispute as a conflict of interest and not one of values-also impel the Bureau to hold a hearing rather than to dispose of the case at this point.

All of the cases where full solutions are promised are closed, and about half of those where less than a total solution is offered also are closed. Upon closing a file with some solution, the $\mathrm{Bu}$ reau sends a form letter to the complainant. ${ }^{72}$

12 The form letter reads as follows:

We have been advised by the above named company/individual that 
The assumptions that the Bureau makes in disposing of cases at this point in the process show a curious mixture of roles. The hearing officers do not represent the complainants in an official sense. Yet the hearing officers accept compromises on behalf of complainants, without obtaining the complainants' agreement, as a mediator would do. Although the hearing officers see themselves as acting for the complainants, they substitute their own judgments in deciding when disputes are resolved equitably and when problems are solved. Resolution thus means not that both parties are satisfied but that the third party is satisfied with the equity of the outcome. The Bureau, however, is not a court. The hearing officers do not act like judges-they do not issue decisions, or have the power to do so. Instead they leave to the seller the initiative of offering potential solutions and apply their standards only negatively to decide whether resolution is to be further encouraged by an informal hearing. The Bureau's decision is based on a judgment of the equity of the case and on the likelihood of obtaining more for the complainant. The decision is not, except in extreme cases, based upon legal rules of liability or upon judgments of the cause of the dispute or the existence of fraudulent conduct.

This set of assumptions is congruent with the Bureau's primary stance of dispute settlement. Once this stance is adopted, the task of the Bureau is defined as moving the seller to an acceptable compromise position somewhere between the original positions of the parties, unless the seller can demonstrate that the complainant is entitled to nothing at all.

\section{Informal Hearings}

Informal Bureau hearings were held on $18 \%$ of the complaints in the sample, $23 \%$ of the cases over which the Bureau had jurisdiction. These hearings are private, held in the hearing officers' cramped offices. If more than four people were present, some would have to sit on window sills or stand. Telephone calls often interrupt the proceedings. The contrast to the public atmosphere of a courtroom is striking. Usually only the hearing officer, the buyer, and the seller are present (though

they have contacted you relative to your complaint, and that they have adjusted the matter to your satisfaction.

Will you please check one of the boxes below and return this letter to our office so that we may close our file.

$\square$ The Company has adjusted my complaint. Please close my file.

The Company has NOT adjusted my complaint. Explain.

The Bureau received very few responses to this letter. 
in $16 \%$ of the hearings the seller's lawyer was also present). People unrelated to the hearing in process wait outside in a reception area.

The procedure also is informal. The Bureau's rules provide for such formal legal rights as subpoenas, presentation of evidence, objection to and exclusion of evidence, argument by the parties, the taking of oaths, and written decisions, but such formalities are seldom observed. Some lawyers representing sellers at informal hearings attempt to operate formally as if they were in a courtroom (with opening and closing arguments, objections to evidence, and cross-examination). The hearing officers usually resist such formalities and, if necessary, tell the attorney such formalities are out of place. At one hearing I attended, an officer said with some annoyance to the seller's lawyer, who had objected to something the complainant said: "Be quiet and let me hear what he has to say. This isn't a trial, you know. We're simply trying to settle this complaint against your client."

TABLE XII

Parties Present at Bureau Hearungs ${ }^{73}$

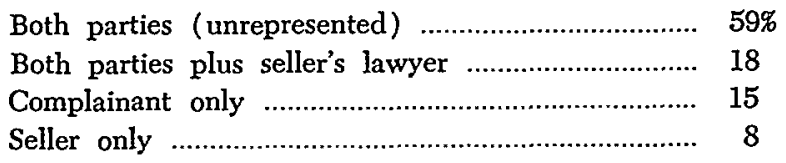

$100 \%(\mathrm{~N}=72)$

Both parties generally were present at hearings. Table XII shows those parties present at hearings held on the complaints in the sample. When the seller is present but the complainant is absent without excuse, the case usually is dismissed. When the complainant is present but the seller is not, the hearing officer generally attempts to call the seller and negotiate over the telephone. If the seller cannot be contacted, the hearing officer generally shifts to a counseling stance toward the complainant-advising him where to go for help (usually a lawyer or the small claims court). ${ }^{74}$ Where both parties were present, the role of the hearing officer was a blend of mediator and judge,

i3 Cases where parties present at hearing could not be determined from records (8) are omitted.

it The impressions are based mainly on discussions with hearing officers and complainants and brief notes about hearings found in the complaint files, because my observation of hearings included only two where one party was absent. 
although the Bureau's rules seem to characterize him more as a judge. ${ }^{75}$

The hearings usually were opened by the hearing officer's stating the problem. ${ }^{76}$ There usually was silence while the hearing officer talked, with no interruption until the parties got a feel for what was expected of them. The hearing officer normally stated the problem from the complainant's point of view, somewhat objectified and modified by the officer's judgment of which parts of the complaint were legitimate, and stripped of the more emotional aspects of the complaint. After several minutes, one party ordinarily interrupted to object to the statement. The cases were about evenly divided as to which party did so first. The objection tended to broaden the area of conflict substantially by interjecting related but separate transactions, emotional overtones, and peripheral relationships. At this point, tempers began to rise, and the dispute started to erupt within the hearing. The task of the hearing officer was then to keep the parties

75 The Bureau's Rules of Procedure provide:

Rule 6. CONDUCT OF HEARING. A hearing is an informal proceeding. The parties shall appear before a duly assigned Hearing Officer. Opportunity shall be afforded to the complainant and respondent to present evidence and argument on all issues involved and to cross-examine all witnesses who have testified. The Hearing Officer may question any party or witness.

[The Bureau] may, on its own motion, subpoena witnesses or tangible evidence. A party may, within a reasonable time before the hearing date, request [the Bureau] to subpoena witnesses or tangible evidence. Such request shall be granted when the Hearing Officer deems it appropriate.

Any relevant evidence which is not privileged is admissible without regard to whether such evidence is hearsay or otherwise inadmissible in a court of law. The Hearing Officer may exclude irrelevant, immaterial or unduly repetitious evidence.

Each party has the right to representation by counsel at his own expense.

Either party or [the Bureau] may cause the hearing to be transcribed at his or its own expense.

The Hearing Officer may make a finding, based on substantial evidence, that a violation of any statute under [the Bureau's] jurisdiction has occurred. The finding shall be reflected in a written order. The respondent and complainant shall be notified either personally or by mail of any such finding or order.

A Hearing Officer may administer an oath or affirmation to any person upon request of either party or upon his own initiative.

A Hearing Officer may expel any party or attorney from any hearing for improper, disorderly, or contemptuous conduct.

Ill. Att'y Gen., Consumer Fraud \& Protection Div. Rules \& Regulations, R. 6.

${ }^{76}$ The description and analysis of informal Bureau hearings which follows is based on my observation of 40 hearings. Although my impressions are necessarily subjective, they were confirmed generally by my discussions with Bureau staff, complainants and businesses, and by the sample complainants interviewed, half of whom had attended hearings. 
focused on the narrow dispute as he had defined it. He had to calm them so that they would accept his definition of the matter as a limited and solvable problem rather than as a matter of principle and a battle of wills where each party's "face" was at stake-the complainant's on the issue whether he had been "taken" in the original transaction, the seller's on whether he would be defeated at the hearing. The task was to transform the dispute from an issue of principle into a solvable problem.

Aubert's distinction between "conflict of interest" and "conflict of values" is useful in conceptualizing the dynamics of the informal hearings. Aubert has written:

A conflict of interest between two actors stems from a situation of scarcity. Both [parties] want "the same thing," but there is not enough of it available for each to have what he wants. In this general sense the basis for a conflict is present in all trading transactions. The seller would like to have more money than the buyer is willing to part with, or he would like to withhold a quantity of the produce which the buyer wants to acquire. This conflict potential is eliminated through the operation of the market, usually so smoothly that no overt signs of conflict appear. If a conflict comes into the open, the solution will often be a compromise. Each party concedes to reduce his demands until an agreement is reached, although possibly still believing that he is contributing too much. This agreement is, therefore, not to be interpreted as an ethical commitment to the price as an expression of the just terms of exchange. It is merely to be interpreted as an expression of what [the parties], under the given market conditions, find it in their own interests to do.

A conflict of value is based upon a dissensus concerning the normative status of a social object.

One may raise the question whether conflicts of values can be avoided in the same fashion as interest conflicts, e.g., by compromise and mutual resignation relative to what seems the ideal solution. It is no doubt possible to formulate statements that contain some elements from one system of values or description and some from another. Such compromises are frequently reached in negotiations between organizations who want to substitute cooperation for competition. The 
terms of exchange are, however, very uncertain in such dealings. A scent of the illicit often pervades such dealings: "one cannot trade in values," "ideas are not for sale," "no bargain with truth," etc. This illicit nature of compromise on the level of value and of empirical truth makes it hard to discuss matters quite candidly, thereby decreasing the chances of reaching a solution. One reason for this, I suppose, is that on the level of dissensus it is hard to tell what is "give" and what is "take."77

The hearing officer's task at the hearing is to impose on the parties the definition of the dispute as a conflict of interest. As we have already seen in analyzing the complaints received by the Bureau, complainants often present their cases as conflicts of interest; yet, when face-to-face with the seller during a hearing, there is often a tendency, as emotions rise, for the conflict of value elements to increase in importance relative to the conflict of interest elements of the dispute.

The hearing officers press sellers to "look the complainant in the eye" and admit the existence of the problems. Similarly, they press complainants to admit the sellers' good faith and to try to view the dispute from the sellers' point of view. If the conflict of interest definition of the dispute can be sustained, the problem usually is solved because neither party then can fail to be "reasonable" and accept a compromise. If the conflict of value definition ultimately prevails, the settlement of the dispute is infrequent. After trying to impose the conflict of interest definition on the dispute, the hearing officer usually attempts to persuade each party to accept his view of what has occurred and to suggest a specific settlement. Such suggested settlements are usually to split the difference between the hearing officer's definitions of the legitimate positions of the parties. The hearing officers say that most of their recommendations are accepted, and the hearings I observed confirmed this. Most of the complainants interviewed said that both they and the sellers were more willing to bargain about the dispute after the intervention of the hearing officer than either had been before, and that the final resolution was the one he had suggested. Of the thirty-eight hearings I attended where both parties were

"Aubert, Competition and Dissensus: Two Types of Conflict and of Conflict Resolution, 7 J. Confl. Resolution 26, 27-29 (1963). 
present, only five resulted in the complainant's obtaining everything he originally thought he was entitled to. In some of the remaining cases, on the basis of the hearing the complainant changed his mind on his entitlement and then got all of that. In the majority of cases, however, the outcome was a compromise based on what the seller would yield and the officer's judgment of the equitable outcome.

If no solution could be reached during the hearing, the hearing officer was obliged to confess his powerlessness to the complainant. As one hearing officer put it, "We can't do any more for you, you'll have to go and see a private lawyer or legal aid. Even if we file suit for you, it will take several years to get an order and we cannot assure you that you will ever get any money." Ultimately, the Bureau is not in a position to file individual lawsuits for complainants, although the statute gives it power to seek restitution in addition to other remedies. Once again, what I have termed the standard of solvability comes into playif a dispute cannot be settled during the hearing it will normally be dropped as unsolvable after a reasonable allocation of $\mathrm{Bu}$ reau resources.

The intervention of the Bureau into disputes is a form of mediation, a blend of the elements of informal problem solving and of more formal adjudication or arbitration. As Aubert has written,

If conflicts move towards a solution they may do so in one of two major ways, through bargaining and compromise and through law and the application of norms to established facts. In a sense the former conflict-solving mechanism presupposes that the conflict is handled as a conflict of interest, while the latter presupposes that it be handled as a dissensus over facts or norms .... [A] variety of conflict-solving mechanisms, intermediary between law and bargaining, are of great interest. A market price may solve conflicts in a way reminiscent of law, as may arbitration, while mediation must be considered a modified type of bargaining. ${ }^{78}$

Aubert seems to be referring to the portion of the dispute management continuum I have described (see Figure I) which lies between the informal pole and the central portion of the continuum. Aubert summarizes the attributes of these two modes

${ }^{78}$ Id. 33. 
of dispute settlement appropriate to the two types of conflict in the form of a list of contrasting characteristics, set out in Figure V. Aubert's "bargain model" lies close to the informal pole of the continuum, his "court model" in the central portion of it.

FIGURE V

Aubert's Two Models of Dispute Resolution ${ }^{79}$

Court Model

a. triad

b. coercive power

c. application of highly valued norms

d. establishment of past facts (guilt)

e. retroactively oriented reasoning

f. legal experts participate (that is, judge)

g. conclusion is a verdict

h. purely distributive decision

i. either/or decision

j. reaffirmation

k. affinity to legal scholarship
Bargain Model

a. dyad

b. no coercive power

c. pursuit of interests (values)

d. not necessary to establish past facts

e. prospectively oriented reasoning

f. no legal experts participate

g. conclusion is an agreement

h. distributive/generative decision

i. a compromise

j. no necessary implication concerning validity

k. affinity to science or utilitarian thinking

The Bureau lies between the court and bargain models of dispute intervention. Although these two models are described as two separate ideal types, they are, I think, to be interpreted as the two endpoints of a continuum of institutions, as Aubert acknowledges when he refers to the "variety of conflict-solving mechanisms, intermediary between law and bargaining."80 One could go further, as Abel has attempted to do, ${ }^{81}$ and analyze the continuum as a series of separate variables which may or

${ }^{79}$ The chart is set out in Nader, Styles of Cout Procedure: To Make the Balance, in Law in Culture and Society 87 (L. Nader ed. 1969).

${ }^{80}$ See text accompanying note 78 supra.

${ }^{81}$ Abel, supra note 12 , at 241 et seq. 
may not vary together as Aubert implies that they do. By this analysis, the institutions intermediary between the two poles or models might be closer to one model on some variables, and closer to the other model on other variables.

The initial Bureau intervention by letter seems in many respects close to Aubert's bargain model. As we have seen, the Bureau acts at this stage primarily as the consumer's advocate in pursuit of the consumer's interests as interpreted by the Bureau. While there is a third party present there is little coercion or assertion of interests separate from those of the parties themselves. The transaction, though not strictly dyadic, is not a fully developed triad because the third party acts in large part on behalf of one of the other parties. The letter intervention is primarily prospectively oriented and seeks a generative compromise agreement, not a decision about past facts or a verdict on the normative quality of past conduct or present positions.

Bureau hearings resemble the court model somewhat more than does Bureau letter intervention. In Bureau hearings the third-party presence is fully developed and unequivocal. The hearing officer no longer acts as a representative of the consumer, but adopts the role of a more neutral mediator whose independent interests include the application of valued norms to ensure that an equitable outcome is reached as well as the resolution of the conflict before him. The hearing officers press for compromise agreements that they feel are equitable, not simply what the parties could be induced to accept, although the basis for the resolution or termination of the dispute remains a bargained agreement rather than a coerced decision. The retroactive assessment of facts by the legal expert (the hearing officer) and the exploration of past conduct for a determination of guilt sometimes takes place during hearings, but it remains a part of the process of mediation and persuasion rather than becoming an attempt to reach an all-or-none distributive verdict. Bureau hearings thus may be characterized as a form of mediation which shares the elements of the bargain and court models suggested by Aubert, and which is located somewhere in the lower (informal) region of the dispute management institution continuum set out in Figure I.

Fuller has described the central quality of mediation as "its capacity to reorient the parties toward each other, not by imposing rules on them, but by helping them to achieve a new and shared perception of their relationship, a perception that 
will redirect their attitudes and dispositions toward one another." 82 Mediation as practiced by the Bureau hearing officers in informal hearings is aimed at reorienting the parties toward each other, not by applying rules to the case at hand but by encouraging the parties to reassess their dispute and their prior positions. This process does not, however, rise to the ideal level implicit in Fuller's words whereby new and shared perceptions are created. Simmel has described the process of mediation as follows:

A third mediating social element deprives conflicting claims of their affective qualities because it neutrally formulates and presents these claims to the two parties involved. Thus this circle that is fatal to all reconciliation is avoided: the vehemence of the one no longer provokes that of the other, which in turn intensifies that of the first, and so forth, until the whole relationship breaks down. Furthermore, because of the nonpartisan, each party to the conflict not only listens to more objective matters but is also forced to put the issue in more objective terms than it would if it confronted the other without mediation. For now it is important for each to win over even the mediator. This, however, can be hoped for only on purely objective grounds, because the mediator is not the arbitrator, but only guides the process of coming to terms; because, in other words, he must always keep out of any decision-whereas the arbitrator ends up by taking sides. Within the realm of sociological techniques, there is nothing that serves the reconciliation of conflicting parties so effectively as does objectivity, that is, the attempt at limiting all complaints and requests to their objective contents. ${ }^{83}$

The result seems more often to be the achievement of mutual resignation to partially fulfilled interests. Mediation by the $\mathrm{Bu}$ reau involves processes such as those described by Fuller and by Simmel, but also involves the ever-present though usually unstated threat of Bureau prosecution, investigation, and public exposure. The tenor and variety of methods employed by $\mathrm{Bu}-$ reau hearing officers in informal hearings seem more akin to

${ }^{82}$ Fuller, Mediation-Its Forms and Functions, 44 So. CAL. L. Rev. 305, 325 (1971).

83 The Sociology of Georg Simmel 147-48 (K. Wolff ed. 1950). 
what Cohen describes in writing of the realities of the contemporary Chinese legal system:

[The concept of mediation] refers to the range of methods by which third persons seek to resolve a dispute without imposing a binding decision. The ... mediator may merely perform the function of an errand boy who maintains contact between parties who refuse to talk to one another. At the other end of the spectrum, he may not only establish communication between parties, but may also define the issues, decide questions of fact, specifically recommend the terms of a reasonable settlement-perhaps even give a tentative or advisory decision-and mobilize such strong political, economic, social and moral pressures upon one or both parties as to leave little option but that of "voluntary" acquiescence. ${ }^{84}$

The styles of mediation used in informal hearings vary among the hearing officers. Although there are procedural rules for the conduct of such hearings, there are no set substantive rules for the fair settlement of disputes because, according to the rules, the hearings are an investigatory stage of a law enforcement process. The result is a highly individualized process of dispute settlement in which the specific methods of mediation used and the standards of equity applied vary among the individual mediators.

\section{E. The Law Enforcement Response}

The law enforcement response of the Bureau is embodied in and effectuated by the Bureau's litigation activity. The litigation department consists of four lawyers and handles all of the investigation and litigation for the metropolitan area. One not acquainted with the Bureau's functioning might assume, based on a casual analogy to criminal law agencies, that the litigation department takes action on the most serious cases as determined by the hearing department. On closer examination it appears that the litigation department operates independently of the complaint-handling process of the hearing department. The law enforcement and complaint-processing functions are performed by separate groups that act almost like separate agencies-each with its own stance (in fact they are called separate "departments"

${ }^{84}$ Cohen, Chinese Mediation on the Exe of Modernization, 54 CAL. L. REv. 1201 (1966). 
by Bureau staff). The "hearing department" processes complaints and the "litigation department," located at the other end of the suite of offices, handles investigations in addition to litigation. Complaints normally do not move through a series of screenings to litigation, as in the typical prosecutorial agency; rather, litigation investigations are initiated independently of single complaints. The overwhelming majority (96\%) of the complaints received by the Bureau are disposed of by the hearing department at one of the three disposition points examined above. ${ }^{85}$ A tiny fraction of the complaints $(0.4 \%)$ go through the complaint-handling process and move on to the litigation department for investigation, subpoena enforcement, or litigation. The remaining $4 \%$ of the complaints that go to litigation are shifted out of the complaint-handling process in midstream because the seller has become the object of litigation department interest on the basis of information obtained independently of the complaint-handling process.

The factors that trigger investigation for possible law enforcement action are not well understood. The standards under which discretion to investigate and prosecute is exercised are always difficult to decipher. ${ }^{86}$ The contents of the files were ambiguous, and the attorneys were vague and uncooperative in discussing this subject except for saying that when many similar complaints are filed against a business it is investigated. Although the Bureau does not systematically monitor the number of complaints against individual businesses, Table XIII demonstrates that Bureau investigation is in fact more frequent in cases where numerous complaints have been received.

Table XIII is based on the complaints in the sample and litigation department records and analyzes the relationship between the number of Bureau complaints against a business and the likelihood of litigation department investigation. Table XIII illustrates that litigation department activity is infrequent in cases where few complaints are received, although other selection criteria appear to be operating. Table XIV summarizes the Bureau's litigation activity for the year 1972. Table XIV is based on information from the Bureau's docket and complaint index

${ }^{85}$ Summarized in Figure IV supra.

${ }^{86}$ F. Miller, Prosecution: The Degision to Charge a Suspect with a Crime (1969); Goldstein, Police Discretion Not To Invoke the Criminal Process: Low Visibility Decisions in the Administration of Justice, 69 YALE L.J. 543 (1960). 
TABLE XIII

Number of Complaints Against Businesses in Sample Compared with Percentage Investigated for Litigation ${ }^{87}$

\begin{tabular}{ccc}
\hline $\begin{array}{c}\text { Number of } \\
\text { Complaints } \\
\text { Against Business }\end{array}$ & $\begin{array}{c}\% \text { of } \\
\text { Sample }\end{array}$ & $\begin{array}{c}\text { \% Investigated } \\
\text { for Litigation }\end{array}$ \\
\hline One & $39 \%$ & $3 \%$ \\
$2-4$ & 18 & 1 \\
$5-10$ & 19 & 4 \\
$11-15$ & 5 & 22 \\
$16-25$ & 5 & 24 \\
$26-50$ & 9 & 55 \\
$51-75$ & 3 & 33 \\
over 75 & 2 & 33 \\
& $100 \%$ & \\
& $\left(\mathrm{~N}^{2}=34\right)$ & $(\mathrm{N}=385)$ \\
\hline
\end{tabular}

and analyzes all litigation activities for the year, not only those related to complaints in the sample described in Table XIII. Subpoena enforcement litigation is excluded from this analysis because it is procedural in nature and not substantive law enforcement. ${ }^{88}$ As Table XIV demonstrates, a sizable proportion of investigations and lawsuits are initiated in cases where few or no complaints have been received, again indicating that the number of complaints is not the only standard that determines the cases to be investigated.

Hearing officers wrote occasional memoranda informing the litigation department of patterns of conduct that had become apparent to them in handling individual complaints, and suggesting further investigation. These memoranda were often very specific, documented with references to specific complaint files and sometimes outside evidence. The hearing officers felt disillusioned, however, about the chances of the litigation department's acting on any of their requests for litigation. According to them, the memoranda usually were ignored. The litigation department had neither investigated nor acted upon any of the few memoranda in the sample of complaint files. The litigation department files examined were rarely based on

${ }^{87} \mathrm{~N}$ is the total number of businesses in the sample-there were 449 complaints against 402 businesses. Cases in which the number of complaints could not be determined $(17)$ are omitted. $N^{t}$ is the total number of businesses in the sample which were investigated by the litigation department.

8* During 1972 the Bureau filed 57 subpoena enforcement suits, $86 \%$ against businesses with less than 5 complaints. 
TABLE XIV

Litigation Department Activity Durung 1972

\begin{tabular}{ccc}
\hline $\begin{array}{c}\text { Number of Bureau } \\
\text { Complaints Against } \\
\text { Businesses Involved }\end{array}$ & $\begin{array}{c}\text { Injunction Suits } \\
\text { \& Assurances } \\
\text { of Voluntary } \\
\text { Compliance Signed }\end{array}$ & $\begin{array}{c}\text { Pending } \\
\text { Investi- } \\
\text { gations }\end{array}$ \\
\hline None & $17 \%$ & $11 \%$ \\
One & 15 & 25 \\
$2-4$ & 11 & 19 \\
$5-10$ & 17 & 16 \\
$11-15$ & 11 & 7 \\
$16-25$ & 8 & 8 \\
$26-50$ & 11 & 9 \\
$51-75$ & 3 & 2 \\
$76-100$ & 2 & 2 \\
over 100 & 5 & 1 \\
& $100 \%$ & $100 \%$ \\
& $(\mathrm{~N}=61)$ & $(\mathrm{N}=198)$ \\
\hline
\end{tabular}

such memoranda; rather, the litigation investigations and subsequent enforcement appear to be based on information received directly by the litigation lawyers from sources other than complainants. Some Bureau staff members said that trade associations, newspapers, reporters, government officials, or influential individuals frequently provided information and even applied pressure inducing the litigation department to act. This may be caused in part by the primary dispute settlement stance of the hearing department toward complaints, which neither changes easily to a law enforcement stance nor relates well to a distinct group with a law enforcement stance.

The dispute settlement stance of the hearing department in its complaint processing is strong and colors the perception of an accusation received from an "interested party" to the dispute-a complainant. Such accusations tend to be discounted as growing out of feelings aroused by the dispute. This attitude seems to influence even the litigation department's reaction to hearing officers' memoranda suggesting law enforcement. One litigation attorney disregarded a memorandum as simply expressing the annoyance of the hearing officer with a business that had been "giving him trouble" by refusing to attend hearings or settle complaints-it was nothing but a "personal vendetta of the hearing officer." Some impetus from outside often seems to be required to focus the litigation department's atten- 
tion on a particular seller and to label that seller as a candidate for law enforcement. Becker has suggested that rules are enforced only when someone provokes their enforcement:

First, enforcement of a rule is an enterprising act. Someone-an entrepreneur-must take the initiative in punishing the culprit. Second, enforcement occurs when those who want the rule enforced publicly bring the infraction to the attention of others .... Put another way, enforcement occurs when someone blows the whistle. Third, people blow the whistle, making enforcement necessary, when they see some advantage in doing so. ${ }^{89}$

Complainants are not perceived as such entrepreneurs; the Bureau typically views them not as blowing the whistle on a culprit to be punished but as seeking help in resolving a dispute with a seller. The analysis of complaints presented in this Article suggests that this is a correct perception of the typical complainant's motives. The dispute settlement stance of the Bureau is premised upon that perception. The entrepreneurial role is left to those others who have interests in seeing businesses prosecuted rather than in having private disputes settled. The hearing officers occasionally attempt the entrepreneurial role themselves, often unsuccessfully. The litigation lawyers act as entrepreneurs in initiating some law enforcement. But much of the entrepreneurial initiative for Bureau law enforcement comes from sources outside the Bureau.

The law enforcement activity of the Bureau is summarized in Table XV, which shows all litigation matters closed during 1972. As the table indicates, $58 \%$ of the Bureau's litigation activity involved the enforcement of subpoenas. Of the 57 subpoena suits, 11 were successful and the business appeared for a hearing, 15 resulted in settlements, 13 could not be served, and 18 were dismissed for various reasons. Only $32 \%$ of the matters handled by the litigation department involved substantive law enforcement, as opposed to preliminary investigations. Of the 41 law enforcement matters, 10 resulted in assurances of voluntary compliance (promises not to engage in consumer fraud, carrying no sanction or admission of past fraud but usable as prima facie evidence in a subsequent lawsuit based on their

${ }^{89}$ H. BECKER, supra note 1 , at 122. 
violation), and 19 were dismissed without court-imposed sanction (6 of these were settled with restitution). Only 12 matters resulted in court orders of law enforcement ( 5 of those by default).

TABLE XV

Litigation Department Matters Closed in $1972^{\circ 0}$

$\begin{array}{lc}\text { Subpoena Enforcement Suits } & \\ \text { appeared for hearing } & 11 \% \\ \text { settled } & 15 \\ \text { cannot locate } & 13 \\ \text { dismissed } & 19 \\ \quad \text { Total } & 58 \\ \text { Total Assurances of Voluntary } & \\ \text { Compliance Signed } & 10 \\ \text { Substantive Lawsuits } & \\ \text { consent orders without restitution } & 7 \\ \text { default judgments } & 5 \\ \text { restitution } & 6 \\ \text { dismissal } \quad 14 \\ \quad \text { Total } & 32 \\ \text { Total } & 100 \%(\mathrm{~N}=98)\end{array}$

This brief examination of the bases for disposition of litigation matters makes it clear that cases frequently are dismissed on the basis of restitution. The litigation department, which embodies the law enforcement stance of the Bureau, thus leans heavily toward a dispute settlement stance. Many lawsuits and investigations are closed on the basis of restitution, with or without additional sanctions. In sum, the litigation department does not make much use of the formal lawsuit, but deals with businesses mainly in less formal and less public ways. Although it is officially the law enforcement arm of the Bureau, in fact the litigation department functions, like the hearing department, with an orientation toward the settlement of two-party disputes rather than toward prosecution and the imposition of sanctions.

so Matters which were investigated but not acted upon are omitted. This table is based on cases closed during 1972 in order to analyze outcomes. Table XIV is based on cases initiated during 1972. Hence the percentages shown in Tables XIV and XV differ. 


\section{F. The Outcomes of Private Disputes}

The outcomes of private disputes resulting from Bureau action are summarized in Table XVI in terms of how many complainants obtained complete, partial, or no solution to the problems stated in their complaints. The distinction between complete and partial solutions is subjective, because many complainants obtained remedies that appear to an outsider to solve completely the stated problems but that differ from the remedies they requested.91 By describing the outcomes of the disputes in terms of the complainants' requests I do not mean to imply that all complainants are entitled to the relief from the sellers that they claim. Rather, the complaint is the only available benchmark against which to measure the effect of Bureau action on the relative positions of buyer and seller. To attempt to judge further the meaning and equity of various outcomes would be an unwarranted, or at least futile, attempt to second-guess the judgment of the complainant and the Bureau.

TABLE XVI

Outcomes of Private Disputes ${ }^{92}$

\begin{tabular}{lcc}
\hline $\begin{array}{c}\text { Outcome of Complainant's } \\
\text { Problem as a Result } \\
\text { of Bureau Action }\end{array}$ & $\begin{array}{c}\text { Percentage of } \\
\text { Cases Where } \\
\text { Bureau Acted }\end{array}$ & $\begin{array}{c}\text { Percentage of } \\
\text { Total Sample }\end{array}$ \\
\hline Complete solution & $39 \%$ & $17 \%$ \\
Partial solution & 31 & 11 \\
No solution & 30 & 72 \\
& $100 \%$ & $100 \%$ \\
& $\left(\mathrm{~N}^{1}=210\right)$ & $(\mathrm{N}=449)$ \\
\hline
\end{tabular}

What substantive solutions were achieved? What actions did the sellers take in response to Bureau contact? Table XVII shows the distribution of dispute outcomes in terms of the actions taken by sellers in response to Bureau contact.

In $38 \%$ of the cases (restitution, $22 \%$, plus performance, $16 \%$ ) the seller took affirmative action to complete the transaction as originally conceived by the buyer. An additional $10 \%$ of the transactions were canceled entirely. The actions resulting from Bureau intervention were various, especially when

${ }^{91}$ See Table XVIII infra.

${ }^{92} \mathrm{~N}^{1}$ omits cases where the Bureau did not contact the seller (211) and where the outcome of the dispute could not be determined (35). 
TABLE XVII

Seller Actions in Response to Bureau INTERvention ${ }^{93}$

Restitution $22 \%$

Performance of incomplete transaction 16

Replacement or repair of defective merchandise ........... 12

Cancellation of contract 10

Adjustment of erroneous debt 6

None

compared with formal court judgments which are limited primarily to the payment of money.

By comparing the types of action taken by sellers in response to Bureau contact with the type of seller action requested by complainants, several aspects of the effect of Bureau action can be seen. As Table XVIII demonstrates, complainants most frequently obtained relief when they specified the relief they were seeking-although they did not always obtain what they specified. Apparently those problems which can be and are defined by the complainant as remediable by specified seller action are solved more readily. Complainants seeking cancellation of transactions and adjustment of erroneous debts most frequently obtained not only relief, but also the type of relief

TABLE XVIII

Reniedies Requested Compared with Remedies Obtained by Complainants ${ }^{\text {o* }}$

\begin{tabular}{lcccc}
\hline & $\begin{array}{c}\text { Completion of } \\
\text { Performance, } \\
\text { Repair or } \\
\text { Remedy } \\
\text { Obtained }\end{array}$ & $\begin{array}{c}\text { Remedy } \\
\text { Resti- } \\
\text { tution }\end{array}$ & $\begin{array}{c}\text { Requested } \\
\text { Adjustment of } \\
\text { Erroneous Debt } \\
\text { or Cancellation }\end{array}$ & $\begin{array}{c}\text { Unspeci- } \\
\text { fied }\end{array}$ \\
\hline Remedy Requested & $52 \%$ & $35 \%$ & $77 \%$ & $59 \%$ \\
Alternative Remedy & 16 & 38 & 8 & 41 \\
No Remedy & 32 & 27 & 15 & $10 \%$ \\
& $100 \%$ & $100 \%$ & $100 \%$ & $(\mathrm{~N}=25)$ \\
& $(\mathrm{N}=49)$ & $(\mathrm{N}=82)$ & $(\mathrm{N}=42)$ \\
\hline
\end{tabular}

- Some remedy.

${ }_{93}$ Cases where the Bureau did not contact the seller (211) and where outcome cannot be determined (35) are omitted.

94 Total $N=198$. Cases where seller was not contacted (211), where no private remedy was requested (37), and where outcome could not be determined (35) are omitted. 
they requested. After cancellation, completion of performance was most frequently obtained when requested. Bureau action was most effective in obtaining cancellation or completion of performance when requested, and was much less effective in obtaining restitution. There was a definite tendency to shift to alternative remedies when restitution was requested, more so than when remedies other than restitution were requested. The Bureau thus appears to function most effectively as an expeditor of transactions that can be salvaged and much less effectively when transactions are beyond repair and can only be terminated, with restitution.

The outcomes of disputes resulting from informal hearings and from Bureau contact with sellers by letter are distinctly different. Although the proportion of complainants obtaining some relief is almost the same, the nature of the relief is quite different, as Table XIX demonstrates. Partial or compromise solutions are much more likely to occur as a result of hearings, and the vast majority of complete solutions result from letter contacts. Two very different processes are being used. The process of letter contact is much more likely to call forth an all-ornone response and to resolve clear cases. The hearing process is used only for those more difficult or uncertain disputes not solved by letter contact and is more likely to result in a compromise or partial solution.

TABLE XIX

Type of Buheau Intervention and Relief Obtained ${ }^{05}$

\begin{tabular}{lcc}
\hline & Letter Contact & Hearing \\
\hline Complete solution & $.44 \%$ & $24 \%$ \\
Partial solution & 25 & 48 \\
No solution & 31 & 28 \\
& $100 \%$ & $100 \%$ \\
& $(\mathrm{~N}=157)$ & $(\mathrm{N}=53)$ \\
\hline
\end{tabular}

Almost all (97\%) of the complaints over which jurisdiction was taken where seller had not performed at all were disposed of without hearing, as compared to $63 \%$ of other cases. Disputes over the quality of goods or services, being more difficult

${ }^{95}$ Cases where Bureau did not contact seller (211) and where outcome could not be determined (35) are omitted. 
to resolve and more likely to result in compromise, more often went to hearing.

What types of seller responses occur as a result of the two processes? As Table XX demonstrates, completion of performance of a transaction and contract cancellation more frequently resulted from letter contact, while replacement, repair, and restitution more often resulted from hearings. "No solution" outcomes resulted almost equally from letter contact and hearings.

TABLE XX

Type of Bureau Intervention and Types of Relief Obtained ${ }^{96}$

\begin{tabular}{lcc}
\hline & Letter Contact & Hearing \\
\hline Performance completed & $19 \%$ & $14 \%$ \\
Cancellation & 19 & 8 \\
Restitution & 20 & 31 \\
Repair or replacement & 10 & 18 \\
No relief & 32 & 29 \\
& $100 \%$ & $100 \%$ \\
& $(\mathrm{~N}=151)$ & $(\mathrm{N}=51)$ \\
\hline
\end{tabular}

The preceding discussion of complaint outcomes is based on data collected from the Bureau's complaint files. One problem arises from the use of such data. As we have seen, the Bureau disposes of cases on the basis of the seller's promise to act or reports that the seller has acted. But just as some defendants do not pay court judgments, some sellers do not follow through on settlements offered. Similarly, some complainants are not satisfied with the settlement on the basis of which the file was closed.

Forty-two complainants were interviewed. The Bureau's complaint files showed that 26 of these 42 complainants had obtained part or all of what they requested. But only 21 of the complainants interviewed said that they had obtained any of what they requested. In 5 cases out of 26 , the Bureau's files thus showed relief for complainants where the complainant said none had been obtained. It is difficult to interpret these responses. In 3 of the 5 cases the dispute simply continued after Bureau action had been completed. In 2 of the 5 cases the seller

${ }_{96}$ Cases where Bureau did not contact seller (211) and where type of relief could not be determined (43) are omitted. 
had offered the buyer a compromise which the buyer found unacceptable before the buyer complained to the Bureau; the seller had offered the same compromise at a hearing and the complainant again found it unacceptable. Although the seller offered some relief, the dispute was not settled. One complaint involved a faulty automobile. The complainant, obviously, wanted it to run properly. The seller agreed to repair it and tried but did not do so successfully; he then did nothing more. The seller thus did something in response to the complaint but did not completely fix the car. On the basis of the seller's agreement to repair the car, however, the Bureau's file was closed. It is difficult to say that the seller did not comply with his agreement with the Bureau, but it is equally difficult to say that the settlement contemplated at the closing of the file actually took place. This case is atypical, but in its own way each Bureau case is atypical. In only one of the cases where the agreement was not carried out did the settlement involve the payment of money by the seller to the complainant. In such a case it is more appropriate to say that there was a breach of an agreement by seller.

Some Bureau complainants have a problem parallel to that of court plaintiffs with unsatisfied judgments in their favor. Like a court, the Bureau does not monitor settlements to determine whether or not sellers actually perform. The Bureau's rationale for failing to follow up on settlements is that complainants will notify the Bureau if the seller defaults and the Bureau can then reopen the matter. But many complainants do not contact the Bureau again; of the five complainants we interviewed who were in this situation, none had contacted the Bureau again. Their attitude seemed to be that nothing would be accomplished because the Bureau had done all it could do. All five were frustrated and angry at both the seller and the Bureau, felt the Bureau had not been of much help, and seemed resigned to the fact that no relief would be forthcoming. Moreover, the Bureau is quite unlikely to take further action when a seller fails to perform on a settlement agreement, even when this is called to the attention of the Bureau.

Only nine complainants ( $2 \%$ of the sample) contacted the Bureau to report that a seller had not performed a promised settlement. In only four of these cases did the Bureau write the seller again to demand performance of its offered settlement. In only one case did the Bureau go further and hold a hearing. In the other five cases, the Bureau simply filed the letter without 
acknowledgment or further action. Where complainants do not report the seller's noncompliance to the Bureau, therefore, they may be correct in sensing that the Bureau has exhausted both its power and its will to obtain relief. The hearing officers express similar resignation, explaining that they have no power to force a seller to do anything. If the seller fails to perform "voluntarily," they say there is nothing more they can do; after they have tried to settle the matter, they must simply leave the parties where they found them and go on to other cases where the Bureau's resources may be more fruitfully used-the solvability standard in action.

\section{G. Complainant Evaluation of the Bureau}

Dissatisfaction with and even hostility toward the Bureau were widespread among those complainants interviewed. ${ }^{97}$ Asked whether they would complain to the Bureau again should they have another consumer grievance, 19 said yes and 23 said no. Even among those who said they would return to the Bureau, there was much dissatisfaction with the Bureau as being too slow, unaggressive, biased, disorganized, and "bureaucratic." But, as many admitted, they knew of no other place to go for help.

Whether the complainants said they would use the Bureau again clearly is related to whether they obtained relief satisfactory to them. Of the 23 complainants who said they would not use the Bureau again in a similar case, 7 had obtained a partial solution and 16 had obtained nothing. Of those obtaining a partial solution (14), $50 \%$ said they would not return to the Bureau. Of those obtaining no relief (21) $76 \%$ said they would not use the Bureau again. Attitudes toward the Bureau thus vary with the outcome of the case. Many of those who expressed dissatisfaction with the Bureau (67\%) were vehement about it. Three complainants said the hearing officer must have been bribed. One said the Bureau had written to the wrong business in his case. Several said hearing officers were incompetent at hearings and did not understand the situations. Several made a general evaluation of the Bureau as incompetent and ineffective. On the other hand, as might be expected, 10 out of 11 of those who said they were satisfied or somewhat satisfied said that the Bu-

97 The cases of the complainants interviewed were evenly divided between hearing and nonhearing dispositions. 
reau had done a good, if slow, job, and that they would use the Bureau again.

\section{The Role of the Bureau}

The Consumer Fraud Bureau does not operate primarily at the formal level of quasi-criminal law enforcement envisioned in its empowering statute, ferreting out and punishing the hard core of dishonest businesses. The Bureau's primary functioning is instead at a more informal level of problem solving and concrete dispute resolution. The dominant stance of the $\mathrm{Bu}-$ reau is dispute settlement. ${ }^{98}$

The Bureau's stance has shifted in the course of a decade (or perhaps it shifted in the process of implementing the statute and setting up the Bureau) from "rid[ding] the State of merchants who habitually employ fraud" by law enforcement to "righting the wrong and recovering the individual's money whenever possible" by acting as the legal representative of the consumer. ${ }^{99}$

98 The problem-solving and law enforcement stances of the Bureau are analogous to the "service style" and "legalistic style" of police behavior described by Wilson. In the Bureau, as in the police departments Wilson describes, one stance or style predominates but does not completely displace the others. There is law enforcement (legalistic style behavior) even in institutions dominated by problem solving (service style behavior). J. Wilson, Varieties of Police Behavior 172-83, 200-01 (1968).

99 The Bureau was set up over a decade ago. The first report of the attorney general after the Bureau was created described the Act and the attorney general's functions under it as follows:

The law is designed to rid the State of Illinois of merchants who habitually employ fraud, deception and misrepresentation in connection with the sale of merchandise, real estate and services.

Under this Act it is the duty of the Attorney General to investigate unlawful practices and he has the power to require written statements and reports, to examine witnesses under oath, to examine merchandise and records, and to impound and retain merchandise and records pursuant to order of court. To carry out his duties, the Attorney General is authorized to issue subpoenas, administer oaths, conduct hearings, prescribe forms, promulgate rules and regulations, and to institute legal proceedings including actions to obtain injunctions and the appointment of receivers.

1962 Ill. Att'y Gen. Rep. 8.

In contrast to this description of the Bureau contained in the first attorney general's report, a recent report describes the Bureau in this way:

The Attorney General's division of Consumer Protection battles fraudulent, deceptive and unfair business practices throughout Illinois. To supplement our principal offices in downtown ... branch offices have now been established the length of the state . . a as well as in the low income sectors [of the city], in the Spanish-speaking community, and in the suburbs. . . Thus, any citizen who feels that he has been duped or wronged in a consumer transaction can file a complaint with the Attorney General, who then becomes the face-to-face legal representative of the citizen in righting the wrong and recovering the individual's money whenever possible.

[1971-1979] ILL. ATt'Y GEN. REP. \& Op. xxii. 
The Bureau functions mainly as a community resource giving direct help to consumers with problems. In effect, the Bureau is providing specialized legal services to the public on a no-fee basis. Most of the cases the Bureau handles are too small to justify the cost of hiring a private lawyer. Some cases were referred to the Bureau by lawyers. The chief of the Bureau articulated this conception of the Bureau as a community resource and advocate for the public while explaining his reasons for limiting our access to the Bureau's hearings and "clients." $\mathrm{He}$ said that he was afraid that if the public knew he had allowed outsiders to see complaints, they would no longer bring their problems to the Bureau with the same trust and confidence as they would take them to their own lawyers; he also invoked the lawyer-client privilege with respect to the confidentiality of the Bureau's files.

The surface Bureau rhetoric, used by all personnel, is that law enforcement is the mission of the Bureau and that the litigation department is where the "action" is. The chief of the Bureau has said, "We've got jurisdiction over anything bad in the way of consumer practices." One litigation attorney told me what the Bureau does: "We go after the crooks-the real fly-by-night predators who cause all the trouble. We throw the book at them and put them out of business or force them out of the state." Yet this description is not entirely believed even as it is being stated. The litigation lawyers are disillusioned as to the likelihood that their efforts will have much impact on fraud in the community. They are intensely aware of the immense practical difficulties of putting together evidence and witnesses and locating and serving process on businesses, and of the political pressure encountered in trying to take aggressive action. The prevailing attitude is similar to that expressed by Philip Schrag.

My departure from the Department of Consumer Affairs was not a resignation of protest but one of disappointment. Although the Commissioner and the city had given the Law Enforcement Division all the political, financial, and legal support that could reasonably be asked (given New York City's proximity to municipal bankruptcy), we were having little discernible impact on the level of consumer fraud in New York.

To be sure, no one would again be deceived by Foolproof Protection, or by any of a dozen major frauds that folded their fine-print contracts as a result of our investigation and action. But at one time during the 
drafting of the Consumer Protection Law, I had actually imagined that a good law, properly administered, could wipe out misleading sales practices altogether. Our experiences shed little light on whether enough law enforcement could ever do the job, but they do suggest that given our toleration of the way in which adversary and judicial systems now operate, the amount of resources constituting "enough" would be more than any government should devote to the problem.

The government, then, cannot alone be expected to stop consumer fraud, at least not unless the courts treat consumer fraud as a serious offense or the public spends money far in excess of its present appropriations. ${ }^{100}$

While the Bureau's hearing officers share this disenchantment with the law enforcement approach, they express the more optimistic feeling that at least individual consumers can be helped with their problems. The hearing officers deal directly with complaining consumers. They get their hands dirty in the day-to-day nagging problems that come to the Bureau. They are continually bombarded by emotional appeals for assistance. Although the facts and issues are rarely clear-cut, it would be difficult not to respond empathically to such consumer complaints. The impulse is strong to share the stance of the consumers wanting help with their problems and to become their advocates. All complaints present problems that buyers are having with sellers and call the sellers' conduct into question. Of course, sellers have problems with consumers too, but these are not the concern of the Bureau and are not brought there. That the Bureau is structured to deal only with consumers' complaints against sellers furthers the process of identification with the consumer and his problems and sensitization to his interests. One hearing officer noted this tendency to sympathize with complainants by comparing himself to a doctor: "A doctor deals with patients every day. Patients tell him their problems and ask for help. The whole point of being a doctor is to help patients. Perhaps if more germs hired doctors and complained about their problems with antibiotics, doctors' attitudes would be different." Constant exposure to one set of interests has led to empathy with or "capture" by the expressed problem-solving

I00 P. SChrag, Counsel for the Deceived 185-88 (1972). 
needs of consumers, and the Bureau has shifted its stance accordingly-by the same process that regulatory agencies are often said to be "captured" by those interests they are set up to regulate.

We have seen that most of the complaints received by the Bureau do seek direct help with consumer problems. The Bureau's dispute settlement stance is thus the most appropriate response to the complainants' expressed interests. Once this stance is adopted, it is self-reinforcing. Experience with and knowledge of the Bureau's stance shapes the knowledgeable public's expectations of how the Bureau will respond, and thus encourages those seeking such a response to use the Bureau. The Bureau has accepted the definition of itself as a community problem-solving resource and communicates this role definition in its public appearances and literature. One Bureau pamphlet entitled "20 Ways not to be 'Gypped' " states:

The Attorney General is the attorney of the people as well as the chief legal officer of the state. Among the many public services offered by this office is a special Consumer Protection Division, created to combat deceptive and fraudulent business practices .... Any Illinois consumer who believes he has been treated unfairly in any transaction can receive assistance from my office. ${ }^{101}$

Another pamphlet states:

Every member of the public is a potential victim of fraud in some unguarded or uninformed moment. This booklet, therefore, is designed ... to tell you exactly how the Attorney General's office can help if you should be made the victim of a fraudulent or deceptive sales scheme.

ALL OF THIS PROTECTION IS IMMEDIATELY AVAILABLE TO YOU WITHOUT CHARGE AS ANOTHER OF THE PUBLIC SERVICES OF THE ATTORNEY GENERAL'S OFFICE.

How effective is this protection? More than 85,000 members of the public throughout Illinois have been assisted. And more than $\$ 3,500,000$ has been recovered for these citizens. This is money that would have otherwise been lost through fraud or deception in individual sales. Most

${ }^{3 a 1}$ Ill. Atr'y Gen., 20 Ways Not to Be Gypped 16 (1970). 
of these purchases ranged from $\$ 15$ to $\$ 25$ and each involved some form of fraud or deception. ${ }^{102}$

The attorney general of the state recently described the Bureau in this way:

The Consumer Fraud Division processes thousands of consumer complaints about shoddy merchandise, fraudulent sales and repairs and many other consumer related problems.

This is the citizen's tool against the unscrupulous merchant who prowls the market place in search of the unwary. ${ }^{103}$

There is something of a chicken-or-egg dilemma here: has the Bureau adapted its response to the complaints that it receives, or has it received the complaints in response to the services that it offers?

Posed in this way, the question is unanswerable. Yet the dilemma clearly indicates the self-reinforcing process that is operating. The result is the creation and maintenance of congruence between the demands of the Bureau's clients and the dispute settlement services that the Bureau offers as a community resource and the consequent minimization of its efforts at law enforcement.

The dispute settlement services of the Bureau are extremely informal. They emphasize concrete problem solving to the almost total exclusion of rule creation or announcement. The settlement process is dominated by a spirit of compromise ("adjustment," not "decision," of disputes) which leads the Bureau to attempt to facilitate a mediated bargaining process between the parties rather than to apply fixed rules. No fixed substantive rules are used or created by the Bureau. Formal legal rules have effect primarily when the Bureau anticipates formal litigation in court. Hearing officers do not announce decisions like judges; instead they urge solutions to problems. Such solutions remain confidential and are not consulted as precedent even within the Bureau. The Bureau has resisted the creation of substantive rules concerning business practices.

102 Ill. Att'y Gen., Your Protection Against Fraudulent Sales, AdverTISING, \& LoANS (undated).

${ }^{103}$ Scott, Law Day' Thoughts for Each of Us to Consider, Daily Law Bulletin (Chicago), Apr. 26, 1973, at 5, col. 1 . 
The Bureau functions so as to ration its resources and maximize its capacity to respond to concrete problems with problemsolving activity. The trade-off is that the Bureau does not invest many resources in the more formal activity of law enforcement and none in rulemaking. ${ }^{104}$ The solvability criterion serves to ensure that Bureau resources are used primarily in cases in which it can solve problems informally. The implicit judgment is that the Bureau's resources (including its power as a state agency) are to be spread in small amounts to help as many complainants as possible rather than concentrated on the sellers who deviate furthest from the legal norms. Those problems of complainants that cannot be solved with a meager ration of Bureau resources are typically left for appeal to other (more formal) institutions if the complainants wish to pursue them.

104 It is this trade-off which has been the focus of critics of Bureau policy. Consumer agencies such as the Bureau, they contend, should limit themselves to enforcing antifraud laws and ignore disputes which do not involve serious fraud; instead of accepting compromises they should hold out for the vindication of all of the consumers' rights. An example of this line of criticism reads:

The most publicized state agency operating against fraud in consumer credit is the Consumer Frauds Bureau of the Office of the Attorney General of New York. This office in its 1966 Report claims to have handled 15,000 consumer complaints in seven years and to have recovered through "mediation and court action $\$ 1,000,000$ for the public. But its powers in this field are only to sue to dissolve corporations for fraud and to enjoin persistent fraudulent practices. There is no criminal offense into which consumer frauds can readily be fitted.

If one talks to Legal Aid workers in New York, one gets an unflattering picture of the usefulness of the Attorney General's office in this field. He is told of persons waiting by the hour to be interviewed, with scant results. That office has no authority to bring civil suits on behalf of private litigants. Therefore, if it cannot effect an adjustment by telephone mediation, it drops the matter and refers the consumer to private counsel or to legal service offices. It has brought few injunctions against fraudulent practices, and it is believed that it has not accomplished very much by voluntary stipulations to desist.

Professor Caplovitz took a dim view of the usefulness of the New York Attorney General's office in a 1968 lecture where he said:

.. there are now 23 states with Consumer Fraud Bureaus attached to the Attorney General's office. But such Bureaus turn out to be a mixed blessing. Unscrupulous companies soon learn that the most that might happen to them after much litigation is that their license might be suspended. Kripke, Gesture and Reality in Consumer Credit Reform, 44 N.Y.U.L. Rev. 1, 44-45 (1969) (footnotes omitted).

Such criticism ignores both the positive dispute settlement functions performed by such consumer agencies and the fact that offering consumers help with their problems is the only way to encourage them to complain to the agency and that such complaints are a necessary source of information for the law enforcement activity of the Bureau. 
Many legal commentators have called for the creation of new mechanisms for the resolution of consumer disputes. ${ }^{105}$ The Bureau has evolved into just such a mechanism. Although its creators intended the Bureau to enforce antifraud laws, the Bureau has instead concentrated its resources on solving consumers' problems and informally settling disputes. The Bureau, created as a relatively formal law enforcement institution, has come to function primarily as a relatively informal dispute managing institution.

${ }^{105}$ S. 2928, 93d Cong., 2d Sess. (1974); D. Caplovitz, supra note 27; Developments in the Law-Deceptive Advertising, supra note 19, at 1132-34. For several recent surveys of the field, see National Institute for Consumer Justice, Redress of Consumer Grievances (1973); P. Schrag, supra note 49, at 200; Eovaldi \& Gestrin, supra note 19; Jones, Wanted: A New System for Solving Consumer Griezances, 25 ARB. J. 234 (1970); Jones \& Boyer, Improving the Quality of Justice in the Marketplace: The Need for Better Consumer Remedies, 40 GEo. WASH. L. REv. 357 (1972); McGonagle, Arbitration of Consumer Disputes, 27 ARB. J. 65 (1972); Mussehl, The Neighborhood Consumer Center: Relief for the Consumer at the Grass-Roots Level, 47 Notre Dame LAw. 1093 (1972); Rice, supra note 19; Special Committee on Consumer Affairs of the Association of the Bar of the City of New York, Toward the Informal Resolution of Consumer Disputes, 27 RECORd of N.Y.C.B.A. 419 (1972); Developments in the Law-Deceptive Advertising, supra note 19; Comment, supra note 19. See generally Hearings on National Consumer Protection, supra note 30; Joint Hearings on S. 707 E' S. 1160, supra note 30. 